\title{
Chaperone proteins and peroxisomal protein import
}

Wim de Jonge, Henk F. Tabak, and Ineke Braakman

\section{Abstract}

Peroxisomes are ubiquitous organelles present in most eukaryotic cells. Their role in cellular metabolism is diverse among species. An array of genes involved in the formation and maintenance of peroxisomes has been discovered, and can be categorised into genes important for protein import into the peroxisome and genes involved in the maintenance of the organelles' size and abundance. Thorough cell biological and biochemical studies revealed great detail about the process of peroxisomal protein import. Although involvement of several classes of molecular chaperone proteins in peroxisomal protein import has been demonstrated, details regarding the mechanistic aspects of chaperone involvement in this process are not known yet. This review aims to discuss peroxisomal maintenance, with the emphasis on protein import. A general overview of chaperone proteins and their role in protein import processes will be used as context to discuss the - possible - roles of chaperone proteins in peroxisomal protein import.

\section{Introduction}

When a protein is synthesized, it faces many difficulties on the pathway to its native, fully folded structure and proper subcellular localisation. Although the roadmap of this pathway is determined by the linear amino-acid sequence of a protein, without help, its maturation will not occur at a high efficiency in a living cell. At this stage, chaperone proteins come into play. Analogous to their human equivalent, they protect the "infant" protein from unwanted inter- and intramolecular interactions in a crowded cellular milieu, ensuring efficient maturation. Chaperones come in various flavours (Hartl and Hayer-Hartl 2002) and similar chaperone systems are found in all kingdoms (Fig. 1).

It is, therefore, easy to envisage that chaperone proteins play an essential role in the living cell. A number of biomolecular processes are supported by chaperone proteins, such as folding and oligomerisation of newly synthesized proteins, protection of proteins from denaturation by environmental stress, protein import into organelles, targeting of proteins for degradation, modulation of protein-protein interactions, and regulation of translation, transcription, and signal transduction pathways. 

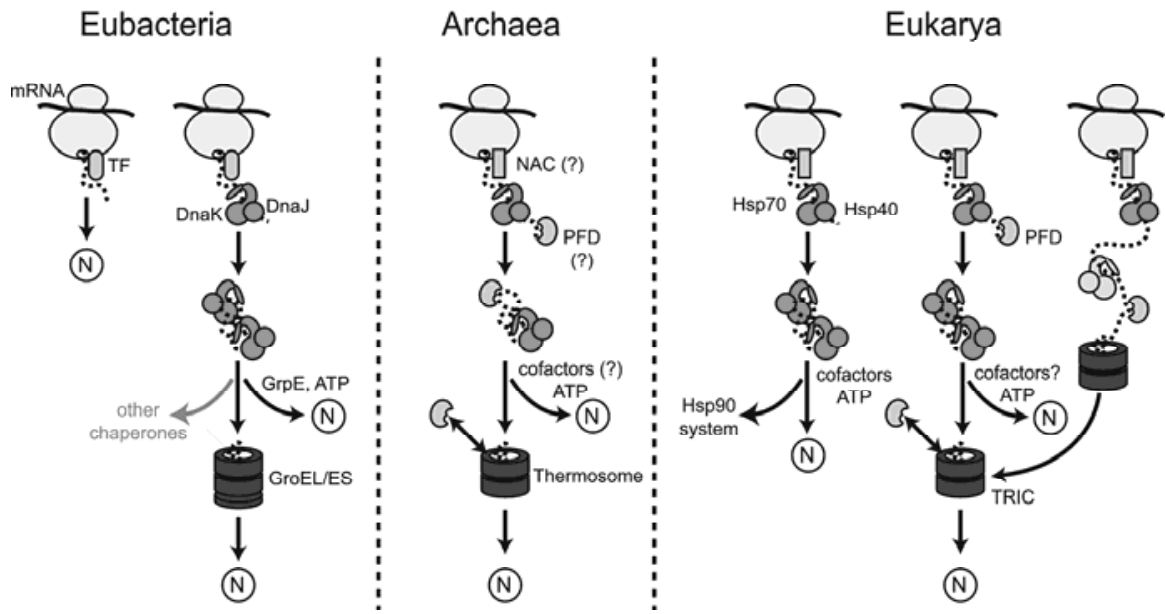

Fig. 1. Variety in chaperone systems. Newly synthesised proteins exit the ribosome, where they first meet ribosome associated chaperones such as trigger factor (TF) in Eubacteria, and nascent chain associated complex (NAC) in Eukarya and possibly in Archaea. Hsp70/40 (DnaJ/K in Eubacteria and Archea) are involved in folding of a part of the pool of newly synthesised proteins, and hand over some proteins to either GroEL/ES in Eubacteria, or similar chaperone systems in Archaea (thermosome) and Eukarya (TRIC). In the latter case, prefoldin serves as a 'targeting factor' for newly synthesised and folding proteins that are client proteins for the TRIC chaperone. Finally, in Eukarya a specific subset of proteins depends on the Hsp90 system for maintaining a proper conformation (Figure adapted and modified after Hartl and Hayer-Hartl 2002).

Chaperones are located in the cytosol and the lumenal cavities of various organelles with the possible exception of peroxisomes. Proteomics studies did not reveal chaperones, except a Lon homolog in mammalian peroxisomes (Kikuchi et al. 2004). Here the chaperones already contribute in the cytosol, which is made possible by the fact that the peroxisomal protein import machinery can accommodate proteins that have attained some conformation. The focus of attention in this review is particularly devoted to the role of chaperones in the formation and maintenance of these remarkable organelles.

\section{Peroxisomes}

\subsection{Formation, maintenance, and function}

Peroxisomes are single-membrane bounded organelles present in all eukaryotic kingdoms, with a variety in appearance and metabolic function. Originally, the organelle was defined as containing hydrogen peroxide $\left(\mathrm{H}_{2} \mathrm{O}_{2}\right)$ producing oxidases, and the $\mathrm{H}_{2} \mathrm{O}_{2}$ detoxifying enzyme catalase, hence the name 'peroxisome'. Examples of peroxisomal metabolic processes are $\beta$-oxidation of fatty acids, parts of the 
Table 1. Peroxins and their main characteristics Abbreviations used: (species) Mamm Mammals, Y - Most yeast species, Sc - Saccharomyces cerevisiae, Y1 - Yarrowia lipolytica, put - putative. (localisation) lum - peroxisomal lumen (matrix), im - integral membrane, pm - peripheral membrane, cyt - cytosol, ? - unresolved or conflicting literature reports.

\begin{tabular}{|c|c|c|c|}
\hline Peroxin & Remarks & Localisation & Species \\
\hline Pexlp & AAA ATPase & cyt, pm & Y, Mamm \\
\hline $\operatorname{Pex} 2 p$ & RING protein, translocase? & im & Y, Mamm \\
\hline Pex3p & Membrane protein stability & $\mathrm{im}$ & Y, Mamm \\
\hline Pex4p & Ubiquitin conjugating enzyme & $\mathrm{pm}$ & $\mathrm{Y}$ \\
\hline Pex $5 p$ & PTS1 receptor & cyt, pm, im, lum (?) & Y, Mamm \\
\hline Pex6p & AAA ATPase & cyt, pm & Y, Mamm \\
\hline $\operatorname{Pex} 7 p$ & PTS2 receptor & cyt, pm, lum (?) & Y, Mamm \\
\hline Pex8p & PTS1 \& PTS2 & pm, lum & $\mathrm{Y}$ \\
\hline Pex9p & Unknown function & $\mathrm{im}$ & Y1 \\
\hline Pex10p & RING protein, translocase? & $\mathrm{im}$ & Y. Mamm \\
\hline Pex11p & Proliferation & $\mathrm{im}, \mathrm{pm}$ & Y, Mamm \\
\hline Pex $12 p$ & RING protein, translocase? & $\mathrm{im}$ & Y, Mamm \\
\hline Pex13p & SH3 domain, docking complex & $\mathrm{im}$ & Y, Mamm \\
\hline Pex14p & Docking complex & $\mathrm{im}, \mathrm{pm}$ & Y, Mamm \\
\hline Pex15p & Phosphorylated & $\mathrm{im}$ & $\mathrm{Sc}$ \\
\hline Pex16p & Membrane protein import & $\mathrm{im}$ & Yl, Mamm \\
\hline Pex 17p & Docking complex & $\mathrm{im}$ & $\mathrm{Sc}$ \\
\hline Pex $18 \mathrm{p}$ & Pex7p co-receptor & cyt & $\mathrm{Sc}$ \\
\hline Pex $19 p$ & Membrane protein import & pm, cyt & $\mathrm{Sc}$ \\
\hline Pex20p & Thiolase import & cyt, pm & $\mathrm{Y} 1$ \\
\hline Pex21p & Pex7p co-receptor & cyt & $\mathrm{Sc}$ \\
\hline $\operatorname{Pex} 22 p$ & Pex4p anchoring & $\mathrm{im}$ & $\mathrm{Sc}$ \\
\hline Pex23p & Protein import & $\mathrm{im}$ & Yl, Sc (put) \\
\hline $\operatorname{Pex} 24 p$ & Protein import & $\mathrm{im}$ & Yl, Sc (put) \\
\hline $\operatorname{Pex} 25 \mathrm{p}$ & Protein import, proliferation & $\mathrm{pm}$ & $\mathrm{Sc}$ \\
\hline Pex26p & Protein import & $\mathrm{im}$ & Mamm \\
\hline Pex27p & Protein import, proliferation & $\mathrm{pm}$ & $\mathrm{Sc}$ \\
\hline Pex $28 p$ & Proliferation & $\mathrm{im}$ & $\mathrm{Sc}$ \\
\hline Pex $29 p$ & Proliferation & $\mathrm{im}$ & $\mathrm{Sc}$ \\
\hline $\operatorname{Pex} 30 p$ & Proliferation & $\mathrm{im}$ & $\mathrm{Sc}$ \\
\hline Pex31p & Proliferation & $\mathrm{im}$ & $\mathrm{Sc}$ \\
\hline $\operatorname{Pex} 32 p$ & Proliferation & $\mathrm{im}$ & $\mathrm{Sc}$ \\
\hline Djplp & $\begin{array}{l}\text { Hsp } 70 \text { co-chaperone, protein } \\
\text { import }\end{array}$ & cyt & $\mathrm{Sc}$ \\
\hline
\end{tabular}

glyoxylate cycle or the glycolytic pathway, photorespiration, methanol catabolism, and penicillin synthesis (Hettema 1998). Although the metabolic functions of peroxisomes are diverse among species, the basic mechanism to maintain the organelle in the cell is conserved throughout evolution. This became apparent upon characterisation of the first serendipitously identified peroxisomal targeting signal (PTS1) of luciferase, an enzyme located in the lantern organ of fireflies, which 


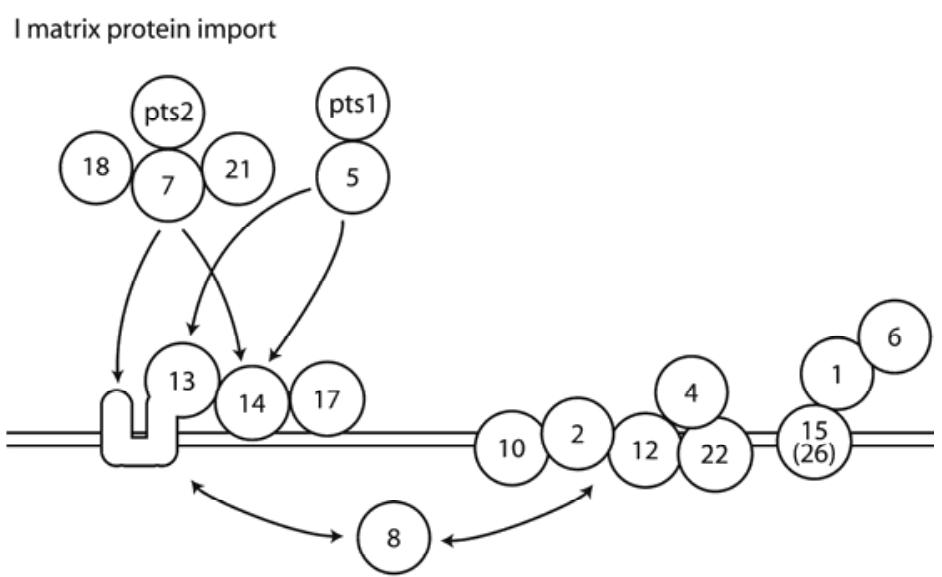

II membrane protein import III peroxisome size and abundance

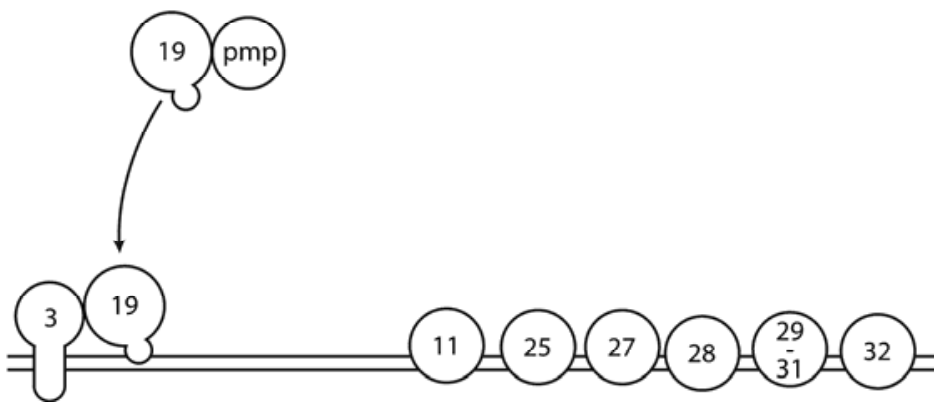

Fig. 2. Overview of peroxins and their interactions. Panel I shows peroxins involved in the import of lumenal proteins. The role of $S$. cerevisiae Pex $15 p$, i.e. tethering Pex1p/Pex $6 p$ to the membrane, is performed by Pex26p in mammals. Panel II shows the few proteins involved in peroxisomal membrane protein import. Panel III lists the peroxins that can influence size and abundance of the organelle. Peroxins are indicated by their number (e.g. Pex $7 p$ is indicated by a 7). Arrows indicate reported interactions. PTS1 - peroxisomal targeting signal type 1 , PTS2 - peroxisomal targeting signal type 2.

was shown to be able to direct a reporter protein to peroxisomes of yeast, mammalian, plant, and insect peroxisomes (Gould et al. 1989, 1990).

Since these initial studies, a series of genetic screens resulted in the characterisation some thirty genes involved in the maintenance of peroxisomes, collectively called peroxins (Distel et al. 1996). A summary of peroxins and their characteristics can be found in Table 1 and Figure 2.

From the early steps in import to the translocation of proteins into the peroxisome, several steps must occur, separated in space and time. In each of these steps, different complexes form and dissociate. In the following paragraphs, an 
overview of the general properties of peroxisomal protein import is presented. Next, some of the discrete steps in the import process are discussed.

\subsection{General properties of protein import}

What are the general requirements for peroxisomal protein import? When ATP is depleted import cannot occur in in vivo, and in semi in vitro experimental systems (Bellion and Goodman 1987; Behari and Baker 1993; Soto et al. 1993; Wendland and Subramani 1993). Because Hsp70, Hsp90, Pex1p, Pex6p, and ANT1 (PMP34) all are ATPases involved in maintenance of, or import into, peroxisomes this is not a surprising finding.

Reports about the intraperoxisomal $\mathrm{pH}$ give conflicting results, the intraperoxisomal $\mathrm{pH}$ varying from alkaline in human fibroblasts (Dansen et al. 2000), filamentous fungi (van der Lende et al. 2002), and yeast (Van Roermund et al. 2004) to neutral in CHO cells and fibroblasts (Jankowski et al. 2001). It is unclear what causes these differences in $\mathrm{pH}$ measurements. Different approaches were used, employing fluorophores coupled to a PTS1, and $\mathrm{pH}$ sensitive forms of GFP fused to a PTS1.

In mitochondria, the $\mathrm{pH}$ gradient across the outer membrane is essential for the import of mitochondrial precursor proteins. Ionophores did inhibit peroxisomal protein import in vivo, suggesting the involvement of a proton gradient in peroxisomal protein import (Bellion and Goodman 1987). Ionophores, however, also diminish the proton gradient across the mitochondrial outer membrane, and thereby, block ATP generation. Therefore, as the authors suggested, the effects observed in vivo may be indirect, via ATP depletion. This result is supported by the observation that, in a mammalian peroxisomal import assay using semipermeabilised cells, ionophores did not inhibit import (Wendland and Subramani 1993). In human fibroblasts, in the absence of import of a subset of peroxisomal proteins, the $\mathrm{pH}$ gradient is diminished. In this situation, a peptide containing a peroxisomal targeting signal coupled to a fluorophore could still be imported into peroxisomes (Dansen et al. 2000). Although it is as yet unclear whether a pH gradient across the peroxisomal membrane exists, it is unlikely that it plays a role in the import of peroxisomal proteins.

\subsection{Proteins involved in protein import}

\subsubsection{PTS1 protein import}

Genes encoding lumenal and membrane peroxisomal proteins are encoded by the nuclear DNA, implying the requirement for a transport machinery that can specifically recognise these proteins and direct them to the peroxisome. At least two different targeting signals have been identified. The canonical peroxisomal targeting signal type 1 (PTS1) consists of the C-terminal tripeptide Serine-Lysine-Leucine or a conserved variant thereof. PTS1 is able to direct reporter proteins to the per- 
oxisomal compartment of many species, but variants of the signal are not always functional across species (Motley et al. 1995; Elgersma et al. 1996b). Detailed mutagenesis studies on the tolerance of deviations from the generic -SKL sequence revealed a role for amino acids upstream of less conserved variants of PTS1 (Elgersma et al. 1996b; Lametschwandtner et al. 1998; Neuberger et al. 2003).

The PTS1 signal can be recognised by Pex5p, a soluble protein that is mainly present in the cytosol. In vitro binding studies show convincingly that Pex $5 \mathrm{p}$ can bind PTS1 independently of other proteins (Fransen et al. 1995; Terlecky et al. 1995; Wiemer et al. 1995a; Klein et al. 2001). The Pex5p-PTS1 interaction appears to be the first specific step in peroxisomal protein import.

The domain responsible for PTS1 recognition is formed by two sets of three TPR motifs in the COOH-terminal half of Pex $5 \mathrm{p}$, connected by a TPR motif-like linker region. TPR motifs are formed by 34 amino acids long antiparallel pairs of alpha-helices, connected by loops, that form a superhelical structure. Mutational analysis of the TPR motifs, combined with homology modelling, revealed a role for residues in the intra-repeat loops of TPR2 and TPR 3 in anchoring the lysine at position 2 of SKL, and for nearby residues in recognising the additional residues of the PTS1. In TPR4-7, a set of asparagine residues can be found that could be involved in interactions with the peptide backbone (Klein et al. 2001). These results were in agreement with the structure of the TPR region of human Pex5p, cocrystallized with a PTS1-peptide (Gatto et al. 2000). In the light of more recent results on the importance of residues upstream of PTS1, this is not the complete picture. Co-crystallisation of a PTS1 protein with Pex5p will explain how proteins with a low affinity PTS1 use accessory amino acid residues to ensure proper recognition by Pex5p.

\subsubsection{PTS2 protein import}

A less common targeting signal is the PTS2, defined as a nonapeptide close to or at the N-terminus with the consensus sequence $\mathrm{R} / \mathrm{K}-\mathrm{L} / \mathrm{V} / \mathrm{I}-\mathrm{X}_{5}-\mathrm{H} / \mathrm{Q}-\mathrm{L} / \mathrm{A}$ (Subramani 1996). PTS2 is necessary and sufficient to direct a reporter protein to peroxisomes (Swinkels et al. 1991; Gietl et al. 1994; Tsukamoto et al. 1994). The few proteins possessing a PTS2 are transported to the peroxisome via the PTS2 receptor Pex $7 \mathrm{p}$, characterised by the presence of WD-40 repeats. Pex $7 \mathrm{p}$ mediated PTS2 import is assisted by either Pex18p/Pex21p (S. cerevisiae), Pex20p ( $Y$. lipolytica) or by an alternatively spliced form of Pex $5 \mathrm{p}$ (mammals). For details, see Section 2.4. Mutational analysis of Pex7p was performed in two independent studies, yet in contrast to the PTS1 - Pex 5p studies, detailed information on structural aspects of Pex $7 p-$ PTS2 recognition is not available yet.

Besides PTS1- and PTS2-mediated import, additional targeting signals have been reported. This concerns rare cases where proteins have found alternative ways to enter peroxisomes. (Interested readers are referred to Klein et al. 2002; Titorenko et al. 2002) 


\subsection{3 mPTS protein import}

Initial research on defining the targeting signal for membrane proteins gave an incomplete picture (Dyer et al. 1996; Jones et al. 2001). Recently, more details about targeting signals for peroxisomal membrane proteins (PMPs) emerged (Rottensteiner et al. 2004). The core sequence was identified as a helical nonapeptide, containing hydrophobic and positively charged amino acids. Although this core sequence is necessary for proper targeting, at least one additional transmembrane region is required for specific insertion into the membrane.

Peroxisomal membrane protein (PMP) insertion depends on Pex3p and Pex19p; in the absence of either one of them, PMPs are mislocalised to the cytosol, and rapidly degraded (Hettema et al. 2000; Jones et al. 2004). Pex3p is an integral membrane protein, and Pex19p is predominantly cytosolic with a small fraction located at the peroxisomal membrane. In cells lacking Pex3 or Pex 19p, peroxisomes are absent, in contrast to the peroxisomal 'ghosts' observed when matrix protein import is blocked. When Pex3p, respectively Pex $19 p$, is re-introduced in these cells, peroxisomes arise again (Hettema et al. 2000; Sacksteder et al. 2000). Pex 19p has been shown to transiently bind newly synthesized PMPs, and requires Pex3p for membrane localisation (Fang et al. 2004; Jones et al. 2004). The current view is that of Pex $19 \mathrm{p}$ as a combined targeting receptor - specialised chaperone for PMPs, which uses Pex3p as a docking factor at the acceptor membrane.

\subsection{Formation of peroxisomes}

The formation of peroxisomes has been a matter of debate since decades, the two extremes being a division model, where peroxisomes multiply by growth and division, and a pathway where the peroxisomal membrane is derived from pre-existing membranes of the endoplasmic reticulum (ER) (Lazarow and Fujiki 1985).

Support for the ER-peroxisome connection was found in morphological studies employing electron microscopy, showing close proximity of peroxisomes to the ER (Novikoff and Novikoff 1972). More recently, direct connections between rough ER and peroxisome precursor structures were detected, shedding new light on the ER-peroxisome connection (Geuze et al. 2003; Tabak et al. 2003).

Attempts to implicate factors involved in classical secretory vesicle transport in the formation of peroxisomes failed (South et al. 2000, 2001; Voorn-Brouwer et al. 2001). In addition, time lapse fluorescence microscopy revealed that, in S. cerevisiae, peroxisomes divide and are transported to the daughter cell, dependent on Vps1p (a member of the dynamin family, and the motor protein Myo2p, respectively (Hoepfner et al. 2001). A similar role in peroxisomal fission was found for Dlp1p in mammalian cells (Koch et al. 2003; Li and Gould 2003).

Logically, a model emerges combining both ideas: peroxisomal membranes are derived from the ER via a non-classical secretion route, grow in size, and divide using a machinery dependent on dynamin-like proteins (Vps1p in yeast, Dlp1p in mammals). 


\subsection{Recycling receptor import model}

\subsubsection{The Pex5p shuttle}

Discussion about functioning of Pex $5 \mathrm{p}$ has mainly focused on localisation of the protein. Most groups report a predominantly cytosolic localisation for Pex 5p, with a small fraction associated with peroxisomes (Van der Leij et al. 1993; Dodt et al. 1995; van der Klei et al. 1995; Wiemer et al. 1995b). The dual localization of Pex $5 p$ led to the proposal of the recycling receptor model: Pex $5 p$ guides peroxisomal proteins from the cytosol to the peroxisomal membrane, where import can occur. After delivery of the peroxisomal protein, Pex $5 \mathrm{p}$ recycles to the cytosol, where it can pick up another peroxisomal protein.

ATP depletion and low temperature block peroxisomal protein import in vivo. Gould and co-workers found that, when studying import into peroxisomes of fibroblasts, these conditions led to a shift in Pex5p localisation from the cytosol to the peroxisome. Taking away these import-blocking conditions resulted in redistribution of Pex5p to the cytosol (Dodt and Gould 1996). Another condition that caused Pex $5 \mathrm{p}$ location to the peroxisome is mutation of PEX2 or PEX12.

\subsubsection{The Pex5p extended shuttle}

Pex $5 p$ was also found inside the peroxisome matrix, as shown by electron microscopy (Szilard et al. 1995; van der Klei et al. 1995). These results led to the notion of an extended recycling receptor model, where Pex $5 p$ traverses the membrane twice: once with PTS1-containing protein into the organelle, and the second time empty to return to the cytosol (Dodt and Gould 1996). This would be a unique situation since, thus far, only the nuclear pore complex has been shown to allow reversible transport of proteins involved in protein cargo movement.

One study aiming to support the extended recycling receptor model used a protease-recognition site, which is specifically cleaved by an intraperoxisomal protease, combined with an epitope tag fused to the $\mathrm{NH}_{2}$-terminus of mammalian Pex5p (Dammai and Subramani 2001). Using antibodies that exclusively recognised the cleaved, exposed epitope tag, the authors showed that Pex $5 \mathrm{p}$ is exposed to the inside of peroxisomes, and recycles back to the cytoplasm. The authors used biochemical criteria to show that Pex5p is present in the peroxisomal matrix, but these results were not conclusive. They did show that the $\mathrm{NH}_{2}$-terminal region of Pex $5 p$ is exposed to the peroxisomal lumen during the import cycle. As an alternative explanation for this result, Pex $5 p$ could function similarly to the bacterial SecA protein. SecA "pushes" proteins through the SecYEG translocon at the cytoplasmic membrane of bacteria by a piston-like motion (Economou and Wickner 1994). Perhaps the $\mathrm{NH}_{2}$-terminus of Pex5p functions as such a piston, explaining why it is at least partially exposed to the peroxisomal lumen. Results from elegant in vitro studies, showing the presence of Pex $5 \mathrm{p}$ inserted into the peroxisomal membrane in different "stages" characterised by differential sensitivity to proteases, might reflect this piston-like motion in the translocation process of peroxisomal proteins (Gouveia et al. 2003). 


\subsubsection{The Pex7p shuttle}

As Pex $5 p$, Pex $7 p$ was reported to be present in the cytosol, at the peroxisomal membrane, and inside the peroxisome (Marzioch et al. 1994; Zhang and Lazarow 1994; Elgersma et al. 1998). Upon deletion of FOX3, the gene encoding 3ketoacyl-CoA thiolase, the only PTS2 protein in yeast, Pex7p could not be detected in the peroxisomal fraction anymore, suggesting that binding of Fox3p enhances peroxisomal localisation of Pex7 (Marzioch et al. 1994). As expected, Pex7p and Fox $3 p$ could be co-immunoprecipitated from a yeast lysate, indicating that Pex7p and Fox3p interact (Rehling et al. 1996).

Pex7p was co-immunoprecipitated with peroxins that are involved in later steps of the import pathway: Pex14p, Pex 17p, and Pex13p. Interestingly, deletion of any of these genes increases the pool of Pex7p-associated Fox3p, strongly suggesting the accumulation of Fox3p in a pre-import stage prior to docking (Girzalsky et al. 1999).

Pex18p and Pex21p are two other proteins involved in the PTS2 pathway. Because they are redundant in function, they were not identified in screens selecting for import defects, but instead by using a two-hybrid approach to identify binding partners of Pex7p. Upon deletion of both PEX18 and PEX21, import of Fox $3 \mathrm{p}$ is abolished, and Pex7p is not found in the peroxisomal fraction upon subcellular fractionation (Purdue et al. 1998). These results led the authors to suggest a chaperone-like role for Pex18p/Pex21p in guiding Pex $7 p$ to the peroxisomal membrane. Because loss of PTS2 protein also abolishes Pex7p association to the peroxisomal fraction, Pex18p and Pex21p, alternatively, may be involved in enhancement of the PTS2-Pex7p interaction, thereby, indirectly enhancing peroxisomal association of Pex 7p. Pex18p and Pex21p are not found in higher eukaryotes, where an alternatively spliced, longer form of Pex $5 \mathrm{p}(\mathrm{Pex} 5 \mathrm{~L})$ appears to take over their role (Dodt et al. 2001). In the absence of Pex5L, PTS2 containing proteins are not imported, and Pex5Lp interacts directly with Pex7p (Braverman et al. 1998; Matsumura et al. 2000).

The PTS2 pathway is not conserved throughout all eukaryotes. It is absent in Caenorhabditis elegans, and proteins that contain a PTS2 in other organisms have acquired a PTS1 in C. elegans (Motley et al. 2000). Another example of evolutionary divergence in the PTS2 pathway occurs in the yeast Yarrowia lipolytica. Here, peroxisomal thiolase is targeted to the peroxisome in the form of a heterotetramer containing two thiolase molecules, and two Pex20p molecules. Pex20p is only found in $Y$. lipolytica, and is the only protein that interacts with thiolase in this particular model organism (Titorenko et al. 1998). Pex20p was suggested to be the ortholog of $S$. cerevisiae Pex $18 \mathrm{p} / \mathrm{Pex} 21 \mathrm{p}$, and Pex5L in mammals (Einwachter et al. 2001). This is likely because Pex18p and Pex21p were duplicated in S. cerevisiae (Dietrich et al. 2004). In addition, Neurospora crassa Pex $7 \mathrm{p}$ acts together with a Y. lipolytica Pex20p in PTS2 import (Sichting et al. 2003). A Pex $7 \mathrm{p}$ homolog has not yet been discovered in Y. lipolytica, however, allowing a role of Pex20p as the principal import receptor for PTS2 proteins. 


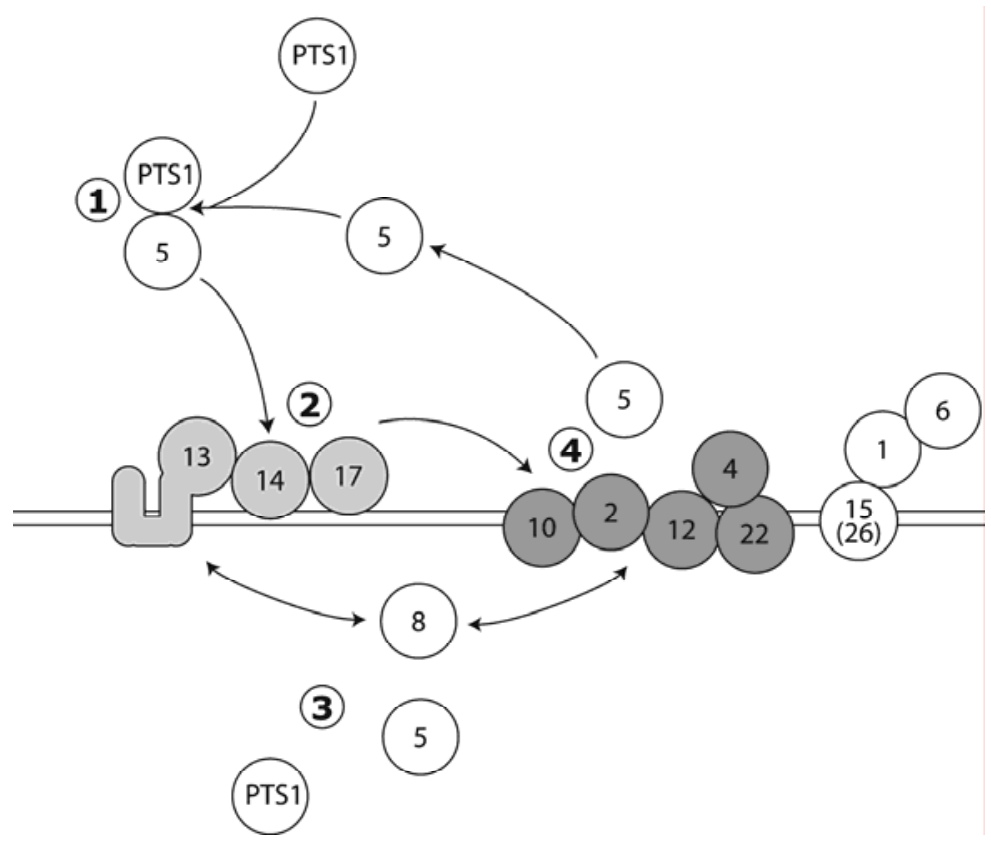

Fig. 3. The peroxisomal protein import cycle. 1. Binding of PTS1 containing cargo to the import receptor Pex 5p. 2. Docking of the cargo-receptor complex onto a membrane protein complex formed by Pex13, Pex14p, and Pex17p. 3. Translocation of cargo and receptor across the peroxisomal membrane and subsequent retro-translocation of receptor. Alternatively, translocation of cargo, and 4. recycling of receptor to the cytosol for a new round of import. Arrows indicate movement and formation/dissociation of protein complexes as cargo and receptor progress through the import cycle. Import receptor and the complexes indicated in light grey and dark grey correspond to membrane subcomplexes I and II (See Section 2.6) whose interactions are orchestrated by the intraperoxisomal Pex8p.

\subsection{Docking and translocation of peroxisomal proteins}

After the initial recognition of the PTS-containing cargo proteins by the cognate receptor, the cargo-receptor complex can interact with proteins at the peroxisomal membrane, a stage in import referred to as docking. Subsequently, the PTS protein will enter the peroxisome, and the receptor will return to the cytosol. This requires two other functionalities: translocation of the cargo, and recycling of the import receptor.

Initial studies suggested that the "docking protein" for Pex5p is Pex13p, an integral peroxisomal membrane protein that contains an SH3 domain (Elgersma et al. 1996a; Erdmann and Blobel 1996; Gould et al. 1996). Later studies revealed that Pex $14 \mathrm{p}$ is the principal protein on which receptor-cargo complexes dock, and where the PTS1 and PTS2 pathways converge: Pex14p can bind both Pex5p and Pex7p (Albertini et al. 1997). Several interaction studies revealed a complex net- 
work of protein-protein interactions, suggesting a cascade of interactions performing the aforementioned functionalities (Agne et al. 2003) (Fig. 3).

A recent investigation using purified components showed that Pex $5 \mathrm{p}$ loaded with PTS1 peptide preferentially interacts with Pex $14 \mathrm{p}$, whereas the empty receptor preferentially interacts with Pex13p (Urquhart et al. 2000). This result suggests that when PTS-containing proteins are "handed over" to the translocation machinery, Pex $5 \mathrm{p}$ possibly relocates to Pex $13 \mathrm{p}$. This study used isolated proteins, and might therefore not represent the events as they occur in protein complexes at the peroxisomal membrane. This caveat becomes more apparent when we consider the complexity of protein assemblies at the peroxisomal membrane, as characterised recently and discussed below (Agne et al. 2003).

Gould and co-workers used the differential instability of Pex $5 p$ in some pex mutants in an attempt to dissect the sequence of events at the peroxisomal membrane (Collins et al. 2000). The authors classified the import mutants into three major groups: the "docking proteins" (Pex13p, Pex14p), the "translocating" proteins (Pex2p, Pex10p, Pex12p), and the proteins involved in recycling of Pex $5 p$ (Pex4p, Pex22p, Pex1p, Pex6p).

Studies on purified protein complexes from rat liver peroxisomes show the existence of two large protein complexes within the peroxisomal membrane. Pex5p and Pex14p form a "core complex", which is more stable than the larger complex found by the same group, which contains Pex2p, Pex12p, Pex5p, and Pex14p (Gouveia et al. 2000; Reguenga et al. 2001). Similar complexes have been found in yeast using affinity purification of subcomplexes from peroxisomal membranes, in an attempt to dissect the sequence of events at the peroxisomal membrane (Girzalsky et al. 1999; Johnson et al. 2001; Hazra et al. 2002). A recent study in $S$. cerevisiae demonstrated a central role for the intraperoxisomal peroxin Pex8p in organising the import-complexes in the peroxisomal membrane (Agne et al. 2003). The authors suggest a working model where the Pex14p/Pex5p/Pex13p/Pex17p complex (I) is the actual translocon and the Pex $2 \mathrm{p} / \mathrm{Pex} 10 \mathrm{p} / \mathrm{Pex} 12 \mathrm{p}$ complex (II) likely plays a role in recycling or in exporting Pex5p to the cytosol. Pex8p was suggested to transfer Pex5p from complex I to complex II, while Pex5p is present in the peroxisomal lumen. A model, combining most results discussed above, is shown in Figure 3.

The models are drawn using Pex $5 p$ as the cycling receptor. Pex $7 p$ likely follows a similar route, depending on the model organism used. In mammals, Pex $7 p$ probably moves with Pex 5p through the import cycles, since Pex5p and Pex7p physically associate (see previous paragraph). In yeast, at least the early steps in import are similar, with a protein assembly like subcomplex I, where Pex $7 \mathrm{p}$ replaces Pex5p. The topology of Pex7p in this membrane complex is unknown as yet. It will be informative to know whether Pex $7 p$, like Pex $5 p$, is inserted in a membrane complex, or remains peripherally associated to the import complexes. Both PTS1 and PTS2 are translocated into the peroxisomal lumen, and therefore, Pex $5 p$ and Pex $7 p$ likely share the machinery for translocation. Within the context of current knowledge about the two import processes, the core translocon is probably formed by (a) component(s) of subcomplex I. 
Although many protein interactions have been charted, insight into the real mechanics of protein translocation across the peroxisomal membrane is lacking. A reliable in vitro protein import system is much needed to increase our knowledge.

\subsection{Folding state and import of peroxisomal proteins}

As most peroxisomal lumenal proteins possess a C-terminal targeting signal, import is a posttranslational event. Already in 1973, Lazarow and de Duve showed that most peroxisomal proteins are synthesised on free polyribosomes (As discussed in Lazarow and Fujiki 1985). This result is underlined by in vivo pulsechase experiments: the import substrates are soluble for quite a long time before they get imported, dependent on the protein concerned (Ruigrok et al. in preparation). Although the protein import machinery of peroxisomes can accommodate at least partially folded proteins, it remains an open question to which extent proteins are folded as they cross the peroxisomal membrane.

At least some degree of folding appears to be tolerated by the peroxisomal import machinery in vivo. Convincing experiments showed that, in S. cerevisiae, the homodimeric enzyme peroxisomal thiolase is imported as a dimer, and that subunits do not mix during the import process. Tagged thiolase lacking a targeting signal could only be recovered as a heterodimer in the peroxisomal fraction, an observation that is highly indicative of "piggy back" translocation of the thiolase lacking the targeting signal (Glover et al. 1994). An often used experimental approach to study the impact of folding on import into mitochondria and the endoplasmic reticulum employs dihydrofolate reductase (DHFR), a protein of which the structure can be stabilised in vivo by aminopterin, and in vitro by methotrexate. Aminopterin was shown not to prevent import into peroxisomes of DHFR fused to a PTS (Hausler et al. 1996).

Another indication that the translocon of peroxisomes is substantially different from ER and mitochondrial import pores is demonstrated by Danpure's work on alanine:glyoxylate aminotransferase 1 (AGT). AGT is a dimeric protein containing both a peroxisomal and a mitochondrial import signal. Wild type AGT dimerises quickly in the cytoplasm, and is imported into peroxisomes. A naturally occurring mutant, causative for the human disease primary hyperoxaluria 1 , prevents dimerisation, resulting in mistargeting of all AGT into mitochondria (Leiper et al. 1996).

An indication of low efficiency of "piggy back" import are experiments performed on peroxisomal malate dehydrogenase $(\mathrm{Mdh} 3 \mathrm{p})$. A massive overexpression of PTS-less tagged Mdh3p was required to force formation of heterooligomers and demonstrate "piggy back" import, perhaps because Mdh3p is one of the faster translocating proteins in vivo (Elgersma et al. 1996b; Ruigrok et al. in preparation). A more recent report shows that Ecilp, a peroxisomal lumenal protein, stripped of its PTS1 can also be transported in a "piggy-back" fashion by oligomerisation with another peroxisomal protein, Dcilp (Yang et al. 2001). Our own studies on kinetics of protein import into peroxisomes in vivo suggest that 


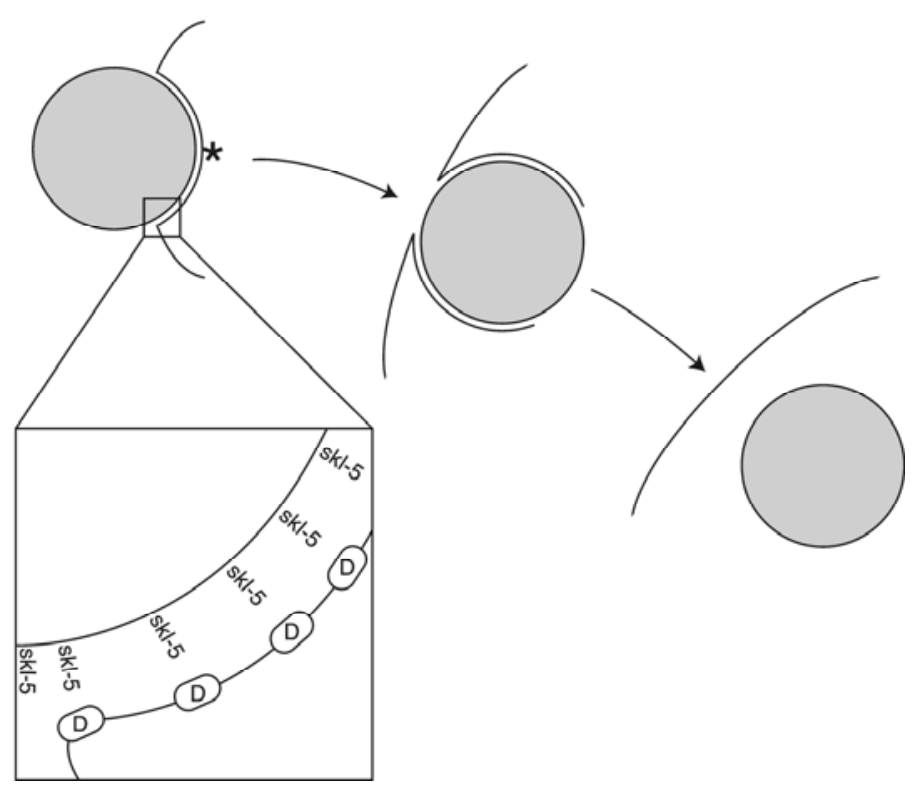

Fig. 4. Putative mechanism for gold particle import. The inset in the first stage of import shows the PTS1-Pex5-Docking complex interaction, which folds the membrane over the gold particle. The asterisk indicates mechanical shearing of the peroxisomal membrane. The membrane slides over the gold particle, and reseals in the last stage, allowing import of the gold particle. Gold particles are depicted in light grey. Abbreviations used: skl-5 PTS1-Pex5p complex, D - Docking proteins at peroxisomal membrane.

newly synthesised proteins destined for the peroxisome are highly importcompetent, as opposed to 'older' import substrate that is not imported yet and gets trapped in an off-pathway state (Ruigrok et al. in preparation).

An example favoured by many authors to support the notion of import of fully folded proteins is the observation that gold particles coated with PTS1-peptides can be imported. Gold particles may not be representative for proteinaceous import substrates; however, it has been reported that hepatocytes take up $17 \mathrm{~nm}$ gold particles from their environment, although, these cells do not display phagocytosis (Hardonk et al. 1985). Perhaps such particles traverse the peroxisomal membrane by physical means. When gold particles are coated with PTS1 peptides, Pex 5p can interact with both PTS1 and peroxisomal membrane proteins, folding the membrane over the particle, and eventually allowing entry by mechanical shearing (see Fig. 4). The physical properties of gold particles (a rigid, non-deformable structure) might allow this type of import, but these are properties that natural import substrates do not possess.

The idea of the peroxisomal membrane engulfing proteins destined for the peroxisome was already postulated by the endocytosis like hypothesis of McNew and Goodman (McNew and Goodman 1996). A more recent opinion paper on the mechanistics of peroxisomal protein import defined the concept of a "preimplex": 


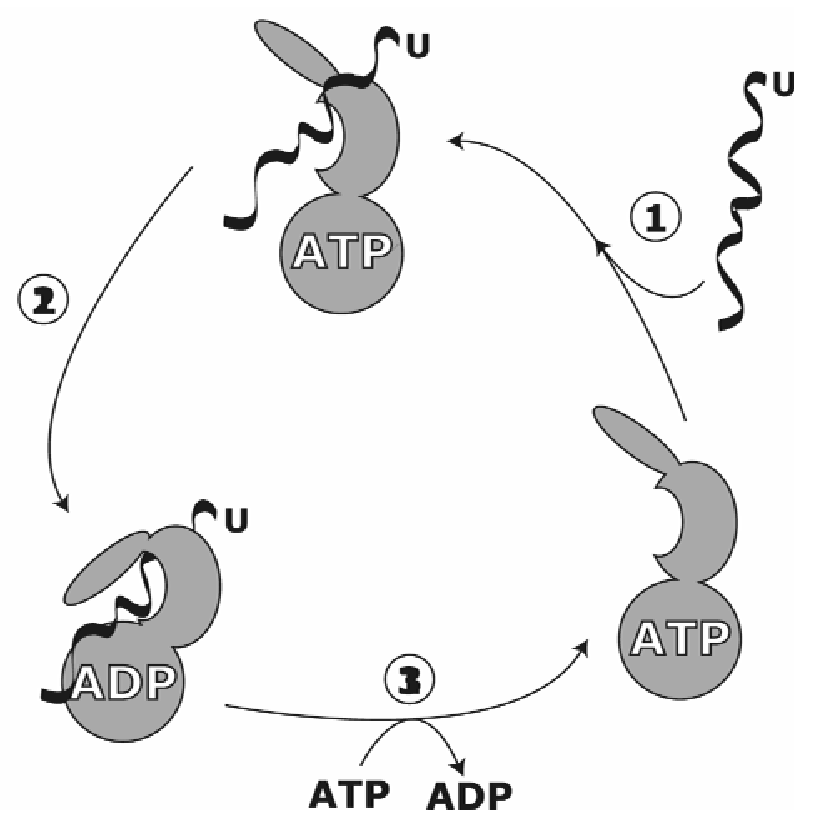

Fig. 5. The chaperone cycle of Hsp70. 1. Binding of substrate to the low-affinity, ATPbound form of Hsp70. 2. Stimulation of ATPase activity by J-proteins induces the conformational change to a tightly bound, ADP-bound form of Hsp70. The client protein is allowed to fold. 3. Nucleotide exchange stimulates the release of the client protein, and returns Hsp70 to the low-affinity, ATP-bound state. See text for further details. Abbreviations used: U - Unfolded, folding, or misfolded client protein, which exposes regions that can be bound by Hsp70. Hsp70 is depicted in dark grey, and "ATP" or "ADP" indicates the nucleotide state within the schematic representation of Hsp70.

an assembly consisting of multiple receptor-cargo complexes with peroxisomal membrane proteins (Gould et al. 2002). Such large complexes would allow import of discrete 'packages' of peroxisomal proteins via an endocytosis-like process, the 'piggy-back' import of oligomerised peroxisomal proteins, and the occurrence of intra-peroxisomal import receptors.

\section{Involvement of Hsp70 in peroxisomal protein import}

\subsection{Hsp70 family introduction}

Hsp70 is an ATPase, and this enzyme activity, located in the N-terminal $44 \mathrm{kDa}$ ATPase domain, is coupled to its chaperone function. When Hsp70 is bound to ATP, it has low affinity for its substrate (folding, or unfolded proteins), whereas the ADP bound state of Hsp70 is characterised by high binding affinity (Schmid et al. 1994). The Hsp70-substrate interaction is mediated by the peptide binding 


\section{Box 1. Hsp70 regulatory proteins}

After hydrolysis of ATP by Hsp70, the final part of the Hsp70 cycle takes place. Here, the exchange of ADP for ATP, which goes hand in hand with the release of substrate is stimulated by regulatory proteins.

In E. coli, chloroplasts, and mitochondria, this function is performed by GrpE (Harrison et al. 1997). In the eukaryotic cytosol and the endoplasmic reticulum, a GrpE-like function is fulfilled by BAG-like proteins like BAG1 (Snllp in S. cerevisiae) in the cytosol, and BAP (Sls1p in S. cerevisiae) in the endoplasmic reticulum (Takayama et al. 1997; Kabani et al. 2000; Chung et al. 2002; Sondermann et al. 2002). BAG-like proteins, which contain the Hsp70regulating "BAG-domain", may be comparable to J-proteins: they use the "BAG-domain" as a module that regulates Hsp70's activity at a specific site in the cell.

In the cytosol, HspBP1 (Fes1p in S. cerevisiae) acts as a negative regulator of Hsp70 nucleotide binding (Raynes and Guerriero 1998; Kabani et al. 2002a). It prevents ATP binding to Hsp70 by stimulating the release of this nucleotide before it can be hydrolysed (Kabani et al. 2002b). In mammals, another protein called HIP can interact with the ATPase domain of Hsp70, stabilising the ADP state (Hohfeld et al. 1995).

Finally, two additional classes of proteins, which interact with the $\mathrm{COOH}-$ terminus of Hsp70, play a role in the substrate binding by Hsp70. HOP (Stilp in S. cerevisiae) plays an organising role in handing over substrate from Hsp70 to the Hsp90 chaperone system, and thus, promotes substrate release from Hsp70 (Nicolet and Craig 1989; Chen and Smith 1998). CHIP negatively regulates substrate release from Hsp70 (Ballinger et al. 1999), and a homologue of CHIP (small glutamine-rich protein/viral protein U-binding protein (SGT/UBP)) also inhibits substrate release from Hsp70 (Angeletti et al. 2002). The latter protein has a homolog in S. cerevisiae (SGT1), but the Hsp70regulating capabilities of this protein have not yet been determined.

domain, which is located C-terminal to the ATPase domain and binds short, mostly hydrophobic, amino acid stretches that are exposed in folding or unfolded proteins (Blond-Elguindi et al. 1993; Rudiger et al. 1997). This on/off cycle of binding prevents unwanted interactions of these hydrophobic segments with the environment (membranes, other proteins), enhancing the chance of productive folding. At the C-terminus of Hsp70 a third domain can be found, often referred to as the 'lid domain'. Upon binding to ATP, Hsp70 is folded such that the peptidebinding domain is freely accessible, allowing the substrate to bind. This interaction is transient in nature, and only upon ATP hydrolysis the conformation of Hsp70 changes such that the peptide is held in the peptide-binding domain, covered by the 'lid domain'. ADP-ATP exchange then changes the conformation of Hsp70, allowing release of the substrate (Buchberger et al. 1995; Mayer et al. 2000) (Fig. 5). 
Although Hsp70 can perform this chaperoning cycle on its own, its activity is highly regulated. The best-studied regulators of Hsp70 are the J-proteins, a family of proteins that is characterised by a so-called J-domain of approximately 70 amino acids. These J-proteins, also referred to as Hsp40s, owe their name to DnaJ, the first identified $E$. coli family member. J-domains specifically interact with Hsp70s, and stimulate their ATP hydrolysis activity (Liberek et al. 1991). The peptide-binding domain of Hsp70 shows little substrate specificity (James et al. 1997). This substrate specificity is provided by J-proteins, present at specific subcellular locations or associated to client proteins, recruiting the Hsp70 chaperone to its target (Silver et al. 1993; Cyr et al. 1994). Several other proteins can influence the ATP-ADP state and substrate binding affinity of Hsp70 (Box1).

Hsp70 has duplicated many times in evolution. Whereas the prokaryote $E$. coli only contains two Hsp70s besides DnaK: HscA and HscC (Kawula and Lelivelt 1994; Itoh et al. 1999), S. cerevisae contains several Hsp70 families, each consisting of one or more family members. During the ancient genome duplication in $S$. cerevisiae, most Hsp70 families were duplicated (Dietrich et al. 2004) (Table 2). The $S S B$ family is ribosome-associated, and presumably acts in early (cotranslational) protein folding. The $S S B$ family binds to nascent chains, as they emerge from the ribosome, an interaction stimulated by Ssz1p in conjunction with the J-protein Zuolp. A four-membered family of Ssa proteins forms another group of cytosolic Hsp70. SSA comprises an essential gene family, and members of the $S S A$ family are functionally redundant, i.e. expression of any of the Ssa proteins can support cell growth in the absence of the other three members (WernerWashburne et al. 1987). Binding of Hsp70 to substrate is not specific across the $S S A$ and $S S B$ families, since exchange of the peptide-binding domain of these chaperone families did not affect their function (James et al. 1997). The SSE family members are Hsp70-like, but contain an insertion, and are thought to function as co-factors in the Hsp90 chaperone machinery. Finally, one or more intraorganellar Hsp70s can be found in ER and mitochondria (see also Section 3.3).

Less detailed information is known about mammalian Hsp70 subfamilies. The distinction between ribosome-bound and cytosolic Hsp70 is not conserved from yeast to mammals, and stress-inducible Hsp70 as well as constitutively expressed Hsc70 isoforms can be found in the cytosol. Besides differential gene expression, no indication exists of functional differences between Hsc70 and Hsp70. For the purpose of simplicity, Hsc70 and Hsp70 will be referred to as Hsp70. As in yeast, an SSE-like family (Hsp105) exists, and intra-organellar Hsp70s can be found in ER, mitochondria, chloroplasts, nucleus, and lysosomes, but not in peroxisomes.

The number of different proteins that can influence the Hsp70 chaperone cycle, Hsp70s' subcellular localisation, and the presence of redundant isoforms of Hsp70 itself reveals an intricate network of regulation, where Hsp70s' activities are regulated in a localised and precise way. A great challenge lies in determining the interplay of these different regulatory networks to ultimately map the way Hsp70s' specificities are achieved in the cell. 
Table 2. Duplications in Hsp70s of S. cerevisiae

\begin{tabular}{lll}
\hline gene & localisation & duplicated (Dietrich et al. 2004) \\
\hline SSA1 & cytosol & no data \\
SSA2 & cytosol & no \\
SSA3 & cytosol & yes $(S S A 4)$ \\
SSA4 & cytosol & yes $(S S A 3)$ \\
$S S B 1$ & cytosol & yes $(S S B 2)$ \\
$S S B 2$ & cytosol & yes $(S S B 1)$ \\
$S S Z 1$ & cytosol & no \\
$S S E 1$ & cytosol & yes $(S S E 2)$ \\
$S S E 2$ & cytosol & yes $(S S E 1)$ \\
KAR2 & ER & no \\
LHS1 & ER & no \\
SSC1 & mitochondria & yes $(E C M 10)$ \\
$E C M 10$ & mitochondria & yes $(S S C 1)$ \\
$S S Q 1$ & mitochondria & no \\
\hline
\end{tabular}

\subsection{In vivo roles of Hsp70}

Hsp70 plays a role in many processes in the cell. Beautiful pulse-chase studies in $E$. coli showed that the E. coli Hsp70 (DnaK) transiently associates with newly synthesized proteins, indicating an important role for Hsp70 in de novo folding of proteins. In yeast, one class of Hsp70s ( $\mathrm{Ssb}$ ) associates to the ribosome and binds the emerging nascent chain of newly synthesized proteins (Nelson et al. 1992; Pfund et al. 1998). Ssb consists of two almost identical family members. Recently, a ribosome-associated J-protein (Zuolp) was found in a stoichiometric complex with an Hsp70-like protein (Ssz1p or Pdr13p), which also localises to the ribosome. Ssz1p itself does not bind nascent chains, but the Ssz1p/Zuolp complex stimulates nascent chain binding to Ssb (Gautschi et al. 2002; Hundley et al. 2002). In mammals, Hsp70 also associates to nascent chains, as was shown in a mammalian translation system (Frydman et al. 1994). Not all proteins, however, depend on Hsp70 for proper cotranslational folding (Nicola et al. 1999).

In yeast, Hsp70s of the cytosolic Ssa family assist at the level of posttranslational folding and perhaps oligomerisation. Maturation of the cytosolic enzyme ornithine transcarbamoylase was followed in a temperature sensitive ssal mutant, in the absence of the other three family members $S S A 2, S S A 3$, and $S S A 4$. At the non-permissive temperature, a large decrease of specific activity of the enzyme resulted and a monomeric species accumulated, suggesting delayed oligomerisation or oligomer disassembly (Kim et al. 1998). The tetrameric enzyme peroxisomal catalase (Cta1p) heavily aggregates in the absence of cytosolic Hsp70 (our own unpublished observations). This also implies a role for Hsp70 in folding of cytosolic proteins.

It is clear that Hsp70 also acts on fully folded proteins. One example is the Jprotein auxillin, which is associated with clathrin-coated vesicles. Auxillin recruits Hsp70 to depolymerise the clathrin coat into free subunits, releasing the vesicle to join the endosomal system (Ungewickell et al. 1995; Pishvaee et al. 2000). An- 
other example of the capability of Hsp70 to bind folded substrates was demonstrated in elegant studies using surface plasmon resonance by Rapoport and colleagues (Misselwitz et al. 1998). Using purified BiP, an ER Hsp70, and the Jdomain of its cognate J-protein Sec63, they showed that BiP can be activated to bind fully folded proteins, provided that the activation of BiP takes place in close proximity to the substrate proteins. Since they could not detect binding to a tightly folded model protein, they assume that $\mathrm{BiP}$ binds portions of the protein that are exposed by "thermal breathing".

\subsection{Hsp70 and import of proteins into organelles}

The role of Hsp70 in protein import processes is diverse and extensively studied. In the next paragraphs, we will highlight some key findings on the role of Hsp70 chaperones in different protein import processes. Our aim is to uncover possible generic mechanisms in Hsp70s functioning in protein import, and to discuss them in the context of peroxisomal protein import. Since peroxisomes do not appear to contain lumenal Hsp70, we will focus our discussion on cytosolic processes prior to import.

Proteins that are destined for import into the ER and mitochondrion traverse the membrane of their target organelle in a partially folded/unfolded state. Two classes of Hsp70 are involved in the import into these organelles: cytosolic and lumenal Hsp70. Cytosolic Hsp70 plays a role in keeping some import substrates in a loosely folded, import competent conformation, whereas lumenal Hsp70 is involved in ensuring unidirectional transport of the polypeptide chain through the translocon.

The role of cytosolic Hsp70 was established in in vivo studies in S. cerevisiae. Partial depletion of cytosolic Hsp70 by deleting one of the four cytosolic Hsp70s SSA1, already resulted in an inability to respire at $37^{\circ} \mathrm{C}$ (Deshaies et al. 1988). This suggests mitochondrial malfunction, possibly caused by diminished import in the absence of sufficient cytosolic Hsp70. To investigate this, later experiments made use of cells where the complete SSA subfamily was deleted, and SSA1 was expressed under control of a regulated promotor to deplete Hsp70 completely in vivo (Deshaies et al. 1988). Pulse-chase experiments revealed precursor accumulation of some but not all mitochondrial and ER precursor proteins. Perhaps some proteins are more easily unfolded, and do not require Hsp70 to keep them loosely folded enough to be translocation competent. Similar observations were made with an ssal-45 temperature sensitive $\left(\mathrm{t}_{\mathrm{S}}\right)$ mutant, also in combination with a $\mathrm{t}_{\mathrm{S}}$ mutant of Ydj1p, one of the cytosolic DnaJ proteins. These results again confirmed the involvement of Ssa proteins in mitochondrial and ER import, and showed that Ydj1p works together with Ssa proteins in this process (Becker et al. 1996).

Some in vitro evidence also underlines a possible role for Hsp70 to keep proteins in an import-competent state. The precursor to mitochondrial aspartate aminotransferase (pmAAT) was chemically denatured, and refolded in the presence of lysate. Hsp70 was shown to associate to pmAAT, which resulted in a form of 
pmAAT that could be imported into isolated mitochondria. However, upon depletion of Hsp70, pmAAT was not competent for import anymore (Artigues et al. 2002). Although this situation is different from that in the living cell - a denatured full-length polypeptide chain instead of vectorially translated protein is used as starting material - it does show that Hsp70 in principle can maintain a protein in an import-competent state. Hsp70 appears to act specifically because cytosolic Hsp90, another cytosolic chaperone, also bound to pmAAT and kept it in a partially folded state but did not allow import of pmAAT into mitochondria. Additional evidence for maintenance of import competence by Hsp70 and/or Hsp40 is the observation that Hsp70/Hsp40 stimulate import of prepro $\alpha$-factor into isolated microsomes by preventing aggregation (Ngosuwan et al. 2002). Using clever experimentation to specifically manipulate levels of ATP outside mitochondria, Asai et al. (2004) showed that cytosolic ATP (and likely cytosolic Hsp70) was important for keeping mitochondrial precursor proteins in an import-competent state.

Although proteins can be presented in a folded state to isolated mitochondria and still be imported efficiently, import occurs more efficiently when the polypeptide chain is (partially) unfolded (Verner and Schatz 1987). A clear example is formed by adenylate cyclase (Adk1p) in yeast. Adk1p is present in the cytosol and mitochondria, a result of competition between Adk1p folding and import (Strobel et al. 2002). Translocation into mitochondria requires unfolded polypeptide, and several factors, including the "pulling" or "trapping" by mitochondrial lumenal Hsp70 and the membrane potential, play a role in actively unfolding the protein at the membrane during translocation (Matouschek et al. 2000; Huang et al. 2002). Studies on the import of a larger set of mitochondrial precursor proteins in vivo would provide us with more insight into the specific requirements of Hsp70 in import into mitochondria.

Unlike the above-discussed classical translocation pores, import into several other organelles allows the imported substrate to be folded and even assembled into oligomers. In nuclear import, medium sized proteins can passively diffuse across the nuclear envelope through an aqueous channel of $9 \mathrm{~nm}$ diameter formed by the nuclear pore. Even larger structures (at least $20 \mathrm{~nm}$ in size) can passage the nuclear pore by active transport. Involvement of Hsp70 in nuclear import was demonstrated using the same conditional mutant in SSA1 (ssal-45) as used to characterise mitochondrial and ER import.

The lysosome (vacuole in yeast) can accommodate import of folded proteins, and different import mechanisms exist. Lysosomes contain lumenal Hsp70s, and a fraction of cytosolic Hsp70 is associated with the lysosomal membrane (Terlecky and Dice 1993; Agarraberes et al. 1997). When mammalian cells are starved for serum, cytosolic proteins containing a KEFRQ amino-acid sequence, are targeted to the lysosome for degradation. Hsc 73 was found to bind to these peptides, and to stimulate lysosomal degradation of a protein containing this sequence in two different in vitro assays (Chiang et al. 1989).

Import of a subset of proteins into yeast vacuoles can involve membrane inclusion of oligomeric protein into small vesicles, termed VID vesicles, which are subsequently targeted to the vacuole. When investigating the influence of Hsp70 
in an in vivo degradation assay, and in an in vitro import assay using isolated VID vesicles, a specific requirement for Ssa2p was found (Brown et al. 2000).

\subsection{Hsp70 and peroxisomal protein import}

Several lines of evidence have implicated Hsp70 in peroxisomal protein import. In a micro-injection based assay, polyclonal antibodies directed against Hsp70 inhibited import of a co-injected PTS1-containing protein. Hsp70 was found to be associated to purified rat liver peroxisomes, and under peroxisome inducing conditions, more Hsp70 associated with peroxisomes (Walton et al. 1994). The PTS2 pathway relies on Hsp70 and Hsp40 for efficient import (Legakis and Terlecky 2001).

Several reports exist on Hsp70s' role in peroxisomal protein import in plants. In cucumber seedlings, two glyoxisomal membrane proteins, PMP73 and PMP61, were shown to be immuno-related to Hsp70 and a DnaJ homologue also present in other plant species (Corpas and RN 1997). Studies in watermelon reveal a Hsp72 gene that could be initiated at two distinct methionines, resulting in a form targeted to plastids, and a form present in the glyoxisomal lumen. The latter localisation was dependent on a PTS2, which was shown to be functional in the yeast $H$. polymorpha (Wimmer et al. 1997). Another group independently reported membrane-associated and lumenal Hsp70 and DnaJ homologs in glyoxisomes (Diefenbach and Kindl 2000). None of the yeast or mammalian Hsp70s carry resemblance to a PTS in their primary structure, suggesting that intraperoxisomal Hsp70 occurs only in the plant kingdom.

In pumpkin seedlings, Hsp70 was found to be peroxisome-associated. The amount of Hsp70 associated with peroxisomes correlated well with the import efficiency: in heat-shocked seedlings more Hsp70 was associated with peroxisomes, and import efficiency increased. As expected, immunodepletion caused a decrease of import into peroxisomes. Hsp70 was suggested to act on the import pathway in the cytosol because prior treatment of peroxisomes with anti-Hsp70 antibody did not affect import. Hsp70 depletion during synthesis of the protein affected import more than Hsp70 depletion after protein synthesis. Taken together with the coimmunoprecipitation of two different import substrates with Hsp70, Hsp70 was concluded to act directly on the import substrate already during its synthesis (Crookes and Olsen 1998).

A recent report directly implicates Hsp70 in peroxisomal protein import via its interaction with Pex5p (Harano et al. 2001). Using the expressed and purified mammalian PTS1 protein acyl-CoA oxidase as bait, both Pex5p and Hsp70 were fished out of mammalian cell lysates. Part of the associated Hsp70 could be released from the complex(es) by ATP, a property indicative of Hsp70-client protein interaction, perhaps reflecting the association of acyl-CoA oxidase with Hsp70.

Other interaction studies, employing PTS1-peptides and purified human Hsp70 and Pex5p, showed that Hsp70 did not have an effect on the binding of Pex $5 p$ to PTS1-peptide. The authors concluded that Pex5p-PTS1 interaction is independent 


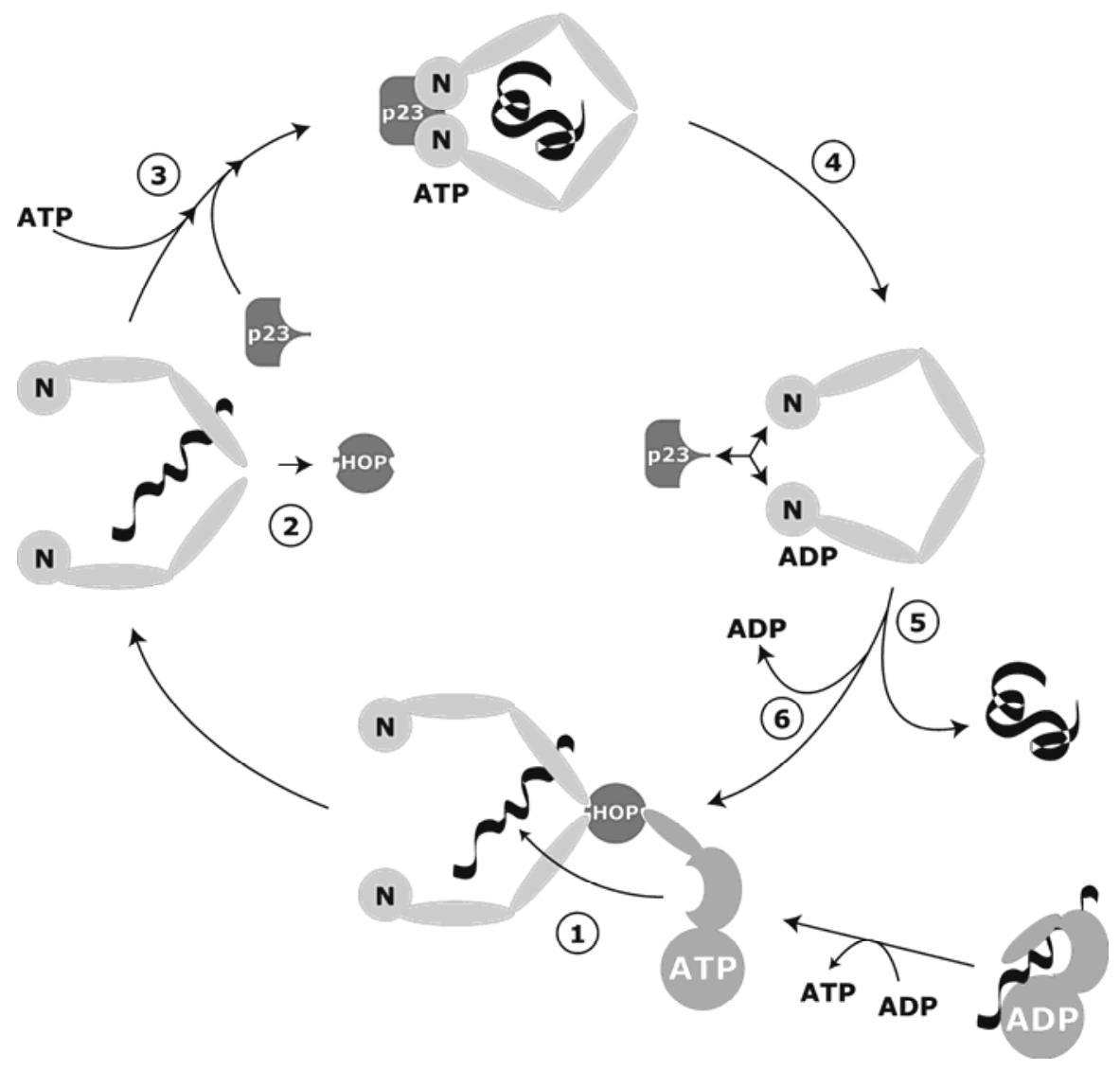

Fig. 6. The chaperone cycle of Hsp90 (After Young et al. 2002). 1. ADP-ATP exchange and substrate release of Hsp70 is stimulated by HOP, which connects Hsp70 to Hsp90. The client protein is next transferred from Hsp70 to Hsp90. 2. HOP dissociates from Hsp90client protein complex, and ATP binds Hsp90, which induces dimerisation of the $\mathrm{NH}_{2}$ terminal domains of Hsp90. 3. p23 binds to the dimerised N-termini of Hsp90. 4. Slow ATP hydrolysis by $\mathrm{Hsp} 90$ causes the $\mathrm{NH}_{2}$-termini to monomerise, p23 dissociates from Hsp90. 5. The substrate is released. 6. ADP dissociates, and Hsp90 returns to its nucleotidefree state, ready to accept new client proteins. Abbreviations used: HOP - Hsp90-Hsp70 Organising Protein. Hsp90 dimers are depicted in light grey, cofactors in dark grey, and Hsp70 in medium grey. The $\mathrm{NH}_{2}$-terminus of $\mathrm{Hsp} 90$ is indicated with an $\mathrm{N}$.

of Hsp70, and that Hsp70 may assist folding and oligomerisation of PTS1 proteins. Because Pex $5 \mathrm{p}$ exists as a tetramer, oligomeric proteins might have higher affinity for Pex $5 p$ than a monomeric protein subunit, resulting in more efficient recognition by Pex5p (Harper et al. 2002).

A general problem with Hsp70 immunodepletion is the specificity of the observed effect. All, or at least a subclass, of Hsp70 is removed prior to the start of an import reaction, which can possibly result in aggregation of the import sub- 
strate, or misfolding of proteins needed for import. Although the in vitro import systems give a rough indication that Hsp70 is involved, more detailed analysis focussing on the interactions between Hsp70 and the different components of the import machinery will be required to understand the role of this chaperone in peroxisomal protein import. Addition problems arise when studying Hsp70s' influence in $S$. cerevisiae. Here several Hsp70 subfamilies, consisting of redundant isoforms, can be found, which makes it difficult to pinpoint which Hsp70 acts in peroxisomal protein import (our unpublished observations).

\section{Involvement of Hsp90 in peroxisomal protein import}

\subsection{Hsp90 family introduction}

The Hsp90 molecular chaperone works in concert with a set of co-factors and with the Hsp70 chaperone system to assist in maintaining the conformation of a specific set of proteins, often involved in signalling pathways, thereby, regulating their function. This protein complex is called the "foldosome" (Hutchison et al. 1994). As for Hsp70, the chaperone function of Hsp90 is coupled to its intrinsic ATPase activity. An outline of the Hsp90 chaperone cycle is depicted in Figure 6.

In initial stages of client protein interaction with Hsp90, Hsp70 hands over the client protein to Hsp90 via a bridging protein called HOP (Hsp70-Hsp90 Organising Protein). HOP contains two domains, consisting of TPR repeats, which bind to a conserved EEVD-COOH motif present on both Hsp70 and Hsp90 (Scheufler et al. 2000). Hsp90 in its nucleotide-free, or ADP bound state is dimeric through interactions in the $\mathrm{COOH}$-terminal region of the protein. HOP is then released from the complex and ATP is bound, inducing dimerisation of the $\mathrm{NH}_{2}$-terminal ATPase domain of Hsp90. This state has a high affinity for $\mathrm{p} 23$. Now ATP hydrolysis occurs, which is a slow step in the Hsp90 cycle. p23, substrate, and ADP are released, and Hsp90 is again in the nucleotide-free state, ready to accept a new client protein.

This "minimal Hsp90 chaperone cycle" is a simplified depiction of the actual situation. The p23-bound state of Hsp90, also referred to as the "mature complex", can contain immunophilins, or immunophilin-like proteins, which act in the maturation of specific substrates.

\subsection{In vivo roles of Hsp90}

Unlike Hsp70, Hsp90 does not appear to function in early events of protein folding at the level of the nascent chains (Frydman 2001). Although refolding studies of denatured model proteins showed that Hsp90 can prevent aggregation and can assist in more efficient refolding (Freeman and Morimoto 1996), the same model proteins are not affected in de novo folding. 
Instead, Hsp90 acts on folded or partially folded proteins to keep them in an active state. This role is exemplified by the well-characterised involvement of Hsp90 in the maturation of signalling proteins such as nuclear hormone receptors, where binding of the receptor to the Hsp90 chaperone machinery ensures that these proteins can be activated by hormones (Picard et al. 1990). Different kinases, such as src- and raf-like kinases and Ste11p in yeast also require Hsp90 for their activity (Xu and Lindquist 1993; Schulte et al. 1995; Louvion et al. 1998). The prominent role of Hsp90 in chaperoning signal transduction pathways explains its being essential in eukaryotes.

\subsection{Hsp90 and import of proteins into organelles}

Demonstrations of the involvement of Hsp90 in protein import processes are scarce. Hsp90 is involved in import of at least some mitochondrial proteins. Hsp90 interacts with various TPR domain-containing proteins, one of which is Tom70p. Tom70p is an outer membrane protein involved in the import of a subset of mitochondrial proteins (Hines et al. 1990). When the interaction between Tom70p and Hsp90 is disturbed, import of Tom70p dependent mitochondrial preproteins does not occur (Young et al. 2003). The authors concluded that Hsp90 targets mitochondrial preproteins to Tom70p. Tom $34 \mathrm{p}$, another protein involved in mitochondrial import also binds Hsp90 (Young et al. 1998). The functional significance of this interaction remains to be established.

Hsp90 is involved in regulating the activity of many signalling proteins. Two examples of signalling proteins, the glucocorticoid receptor (GR), and the dioxin receptor (DR) are targeted to the nucleus in an Hsp90-dependent fashion. Adding geldanamycin, an Hsp90 ATPase inhibitor, to living cells inhibited nuclear import of GR-GFP and DR-GFP fusion proteins. This mechanism appears to rely on immunophilins or immunophilin-like proteins, present in late Hsp90 complexes: FKBP52 and XAP1 for GR and DR, respectively (Silverstein et al. 1999; Kazlauskas et al. 2002). Upon ligand binding to GR, FKBP52 is recruited to the Hsp90-GR complex, and mediates transport of this complex along the cytoskeleton towards the nucleus (Davies et al. 2002). This process is probably mediated via the interaction of FKBP52 with dynein (Galigniana et al. 2002).

As previously mentioned, lamp2a-mediated lysosomal import involves cytosolic Hsp70. Hsp90 is also involved in this import process. Several components of the Hsp90 machinery can associate with import substrates and the lamp2a translocon. Antibodies directed against Hsp70, Hsp40, Hip, or Hop inhibit import into isolated lysosomes. The Hsp90 chaperone machinery might act as a targeting factor for KEFRQ-containing proteins, and/or assist in their translocation (Agarraberes and Dice 2001). 


\subsection{Hsp90 and peroxisomal protein import}

The first report implicating Hsp90 in peroxisomal protein import showed that addition of anti-Hsp90 antibodies to an in vitro plant peroxisomal import assay resulted in retarded import of isocitrate lyase (Crookes and Olsen 1998). The role of Hsp70 was different from that of Hsp90: the effect of anti-Hsp90 antibody was pronounced when added both during synthesis and after synthesis, whereas the major effect of anti-Hsp70 antibodies was during synthesis, suggesting a posttranslational role for Hsp90. We recently found retarded import of both PTS1 and PTS2 containing proteins in the absence of functional Hsp90 in yeast (our unpublished observations). This general import defect could be informative regarding the function of Hsp90 in peroxisomal protein import. Three possibilities come to mind: 1) Hsp90 acts on the PTS-containing protein, 2) Hsp90 acts at the level of import receptors, 3) Hsp90 acts indirectly through signal transduction.

Arguing against the first scenario is the lack of involvement in de novo folding by Hsp90. Hsp90 is found in complex with some nuclear, mitochondrial, and lysosomal proteins and has an active role in their transport. In contrast, in the aforementioned in vitro import assay, antibodies directed to Hsp70 precipitated isocitrate lyase, but an interaction between this import substrate and Hsp90 was not observed. This finding suggests that Hsp90 does not act on peroxisomal protein import via interaction with the peroxisomal proteins prior to import, but the same conclusion need not necessarily apply to all peroxisomal proteins.

The second scenario would imply that both the PTS1 and the PTS2 receptor are chaperoned by Hsp90, resulting in a more efficient function of these receptors in the import process. In line with this notion is the observation that Pex5p can be coimmunoprecipitated with $\mathrm{Hsp} 90$ using in vitro translated proteins (Pratt et al. 2001). Perhaps Hsp90 has a direct role in keeping Pex5p "receptive" for PTS1 recognition. Despite several attempts, we did not find an interaction between Pex5p and Hsp90 in yeast lysates, and therefore, could not confirm this hypothesis (our unpublished observations).

In the final scenario, Hsp90 functions at a later step in peroxisomal protein import, where the PTS1 and PTS2 pathways converge. In this context, it is interesting to note that some peroxins are phosphorylated in vivo (Elgersma et al. 1997; Komori et al. 1999). By regulating the activity of kinases, Hsp90 could regulate activity of peroxins.

\section{Concluding remarks}

Despite the considerable efforts to delineate the contribution of protein folding and chaperones in the process of peroxisomal protein import our insights remain rather limited and fragmentary. This is due to a number of drawbacks:

i. The difficulty to establish the degree of folding in vivo of a protein before, during, or after its itinerary from cytosol into the organelle. 
ii. The lack of success in establishing a reliable in vitro system to study the import of proteins into peroxisomes. This limits experimentation to intact or semi-permeabilised cells, which makes it difficult to distinguish between direct and indirect effects of manipulation. Also, it limits the ability to determine at which step along the import pathway and effect is exerted.

iii. The complexity and redundancy of chaperone families and their regulators makes it difficult to trace the contribution of individual chaperone proteins, even in a genetically tractable organism as $S$. cerevisiae. Most experiments performed in mammalian cells use antibodies, which remove a complete subclass of chaperones, and it is difficult to assess where the chaperone function acts in the import process.

At this moment it is almost impossible to extract a coherent picture about the role of folding and chaperones from the mosaic of various reported observations. Improvement of this impasse awaits the development of in vitro techniques to reconstitute partial steps in the peroxisomal protein import pathway.

\section{References}

Agarraberes FA, Dice JF (2001) A molecular chaperone complex at the lysosomal membrane is required for protein translocation. J Cell Sci 114:2491-2499

Agarraberes FA, Terlecky SR, Dice JF (1997) An intralysosomal hsp70 is required for a selective pathway of lysosomal protein degradation. J Cell Biol 137:825-834

Agne B, Meindl NM, Niederhoff K, Einwachter H, Rehling P, Sickmann A, Meyer HE, Girzalsky W, Kunau W-H (2003) Pex8p: An intraperoxisomal organizer of the peroxisomal import machinery. Mol Cell 11:635-646

Albertini M, Rehling P, Erdmann R, Girzalsky W, Kiel JAKW, Veenhuis M, Kunau W-H (1997) Pex14p, a peroxisomal membrane protein binding both receptors of the two PTS-dependent import pathways. Cell 89:83-92

Angeletti PC, Walker D, Panganiban AT, Wu Y, Hu Z, Thompson LJ, Yin LY, Patterson C (2002) Small glutamine-rich protein/viral protein U-binding protein is a novel cochaperone that affects heat shock protein 70 activity. Cell Stress Chaperones 7:258-268

Artigues A, Iriarte A, Martinez-Carrion M (2002) Binding to chaperones allows import of a purified mitochondrial precursor into mitochondria. J Biol Chem 277:25047-25055

Asai T, Takahashi T, Esaki M, Nishikawa S, Ohtsuka K, Nakai M, Endo T (2004) Reinvestigation of the requirement of cytosolic ATP for mitochondrial protein import. J Biol Chem 279:19464-19470. Epub 12004 Mar 19464

Ballinger CA, Connell P, Wu Y, Hu Z, Thompson LJ, Yin LY, Patterson C (1999) Identification of CHIP, a novel tetratricopeptide repeat-containing protein that interacts with heat shock proteins and negatively regulates chaperone functions. Mol Cell Biol 19:4535-4545

Becker J, Walter W, Yan W, Craig EA (1996) Functional interaction of cytosolic hsp70 and a DnaJ-related protein, Ydj1p, in protein translocation in vivo. Mol Cell Biol 16:43784386 
Behari R, Baker A (1993) The carboxyl terminus of isocitrate lyase is not essential for import into glyoxysomes in an in vitro system. J Biol Chem 268:7315-7322

Bellion E, Goodman JM (1987) Proton ionophores prevent assembly of a peroxisomal protein. Cell 48:165-173

Blond-Elguindi S, Cwirla SE, Dower WJ, Lipshutz RJ, Sprang SR, Sambrook JF, Gething MJ (1993) Affinity panning of a library of peptides displayed on bacteriophages reveals the binding specificity of BiP. Cell 75:717-728

Braverman N, Dodt G, Gould SJ, Valle D (1998) An isoform of pex5p, the human PTS1 receptor, is required for the import of PTS2 proteins into peroxisomes. Hum Mol Genet 7:1195-1205

Brown CR, McCann JA, Chiang HL (2000) The heat shock protein Ssa2p is required for import of fructose-1, 6-bisphosphatase into Vid vesicles. J Cell Biol 150:65-76

Buchberger A, Theyssen H, Schroder H, McCarty JS, Virgallita G, Milkereit P, Reinstein J, Bukau B (1995) Nucleotide-induced conformational changes in the ATPase and substrate binding domains of the DnaK chaperone provide evidence for interdomain communication. J Biol Chem 270:16903-16910

Chen S, Smith DF (1998) Hop as an adaptor in the heat shock protein 70 (Hsp70) and hsp90 chaperone machinery. J Biol Chem 273:35194-35200

Chiang HL, Terlecky SR, Plant CP, Dice JF (1989) A role for a 70-kilodalton heat shock protein in lysosomal degradation of intracellular proteins. Science 246:382-385

Chung KT, Shen Y, Hendershot LM, Siegers K, Moarefi I, Wente SR, Hartl FU, Young JC (2002) BAP, a mammalian BiP-associated protein, is a nucleotide exchange factor that regulates the ATPase activity of BiP. J Biol Chem 277:47557-47563

Collins CS, Kalish JE, Morrell JC, McCaffery JM, Gould SJ (2000) The peroxisome biogenesis factors pex $4 p$, pex $22 p$, pex $1 p$, and pex6p act in the terminal steps of peroxisomal matrix protein import. Mol Cell Biol 20:7516-7526

Corpas F, Trelease RN (1997) The plant $73 \mathrm{kDa}$ peroxisomal membrane protein (PMP73) is immunorelated to molecular chaperones. Eur J Cell Biol 73:49-57

Crookes W, Olsen LJ (1998) The effects of chaperones and the influence of protein assembly on peroxisomal protein import. J Biol Chem 273:17236-17242

Cyr DM, Langer T, Douglas MG (1994) DnaJ-like proteins: molecular chaperones and specific regulators of Hsp70. Trends Biochem Sci 19:176-181

Dammai V, Subramani S (2001) The human peroxisomal targeting signal receptor, Pex5p, is translocated into the peroxisomal matrix and recycled to the cytosol. Cell 105:187196

Dansen TB, Wirtz KW, Wanders RJ, Pap EH, Behari R, Baker A (2000) Peroxisomes in human fibroblasts have a basic $\mathrm{pH}$. Nat Cell Biol 2:51-53

Davies TH, Ning YM, Sanchez ER (2002) A new first step in activation of steroid receptors: hormone-induced switching of FKBP51 and FKBP52 immunophilins. J Biol Chem 277:4597-4600

Deshaies RJ, Koch BD, Werner-Washburne M, Craig EA, Schekman R (1988) A subfamily of stress proteins facilitates translocation of secretory and mitochondrial precursor polypeptides. Nature 332:800-805

Diefenbach J, H K (2000) The membrane-bound DnaJ protein located at the cytosolic site of glyoxysomes specifically binds the cytosolic isoform 1 of Hsp70 but not other Hsp70 species. Eur J Biochem 267:746-754

Dietrich FS, Voegeli S, Brachat S, Lerch A, Gates K, Steiner S, Mohr C, Pohlmann R, Luedi P, Choi S, Wing RA, Flavier A, Gaffney TD, Philippsen P (2004) The Ashbya 
gossypii genome as a tool for mapping the ancient Saccharomyces cerevisiae genome. Science 304:304-307. Epub 2004 Mar 2004

Distel B, Erdmann R, Gould SJ, Blobel G, Crane DI, Cregg JM, Dodt G, Fujiki Y, Goodman JM, Just WW, Kiel JAKW, Kunau W-H, Lazarow PB, Mannaerts GP, Moser HW, Osumi T, Rachubinski RA, Roscher A, Subramani S, Tabak HF, Tsukamoto T, Valle D, van der Klei I, van Veldhoven PP, Veenhuis M (1996) A unified nomenclature for peroxisome biogenesis factors. J Cell Biol 135:1-3

Dodt G, Braverman N, Wong C, Moser A, Moser HW, Watkins P, Valle D, Gould SJ (1995) Mutations in the PTS1 receptor gene, PXR1, define complementation group 2 of the peroxisome biogenesis disorders. Nat Genet 9:115-125

Dodt G, Gould SJ (1996) Multiple PEX genes are required for proper subcellular distribution and stability of Pex5p, the PTS1 receptor: evidence that PTS1 protein import is mediated by a cycling receptor. J Cell Biol 135:1763-1774

Dodt G, Warren D, Becker E, Rehling P, Gould SJ (2001) Domain mapping of human PEX5 reveals functional and structural similarities to Saccharomyces cerevisiae Pex18p and Pex21p. J Biol Chem 276:41769-41781

Dyer JM, McNew JA, Goodman JM (1996) The sorting sequence of the peroxisomal integral membrane protein PMP47 is contained within a short hydrophilic loop. J Cell Biol 133:269-280

Economou A, Wickner W (1994) SecA promotes preprotein translocation by undergoing ATP-driven cycles of membrane insertion and deinsertion. Cell 78:835-843

Einwachter H, Sowinski S, Kunau WH, Schliebs W (2001) Yarrowia lipolytica Pex20p, Saccharomyces cerevisiae Pex18p/Pex $1 \mathrm{p}$ and mammalian Pex $5 \mathrm{pL}$ fulfil a common function in the early steps of the peroxisomal PTS2 import pathway. EMBO Rep 2:1035-1039. Epub 2001 Oct 1017

Elgersma Y, Elgersma-Hooisma M, Wenzel T, McCaffery JM, Farquhar MG, Subramani S (1998) A mobile PTS2 receptor for peroxisomal protein import in Pichia pastoris. J Cell Biol 140:807-820

Elgersma Y, Kwast L, van den Berg M, Snyder WB, Distel B, Subramani S, Tabak HF (1997) Overexpression of Pex15p, a phosphorylated peroxisomal integral membrane protein required for peroxisome assembly in $S$. cerevisiae, causes proliferation of the endoplasmic reticulum membrane. EMBO J 16:7326-7341

Elgersma Y, Kwast L, Klein A, Voorn-Brouwer T, van den Berg M, Metzig B, America T, Tabak HF, Distel B (1996a) The SH3 domain of the Saccharomyces cerevisiae peroxisomal membrane protein Pex13p functions as a docking site for Pex $5 \mathrm{p}$, a mobile receptor for the import of PTS1-containing proteins. J Cell Biol 135:97-109

Elgersma Y, Vos A, van den Berg M, Van Roermund CW, van der Sluijs P, Distel B, Tabak HF (1996b) Analysis of the carboxyl-terminal peroxisomal targeting signal 1 in a homologous context in Saccharomyces cerevisiae. J Biol Chem 271:26375-26382

Erdmann R, Blobel G (1996) Identification of Pex13p, a peroxisomal membrane receptor for the PTS1 recognition factor. J Cell Biol 135:111-121

Fang Y, Morrell JC, Jones JM, Gould SJ (2004) PEX3 functions as a PEX19 docking factor in the import of class I peroxisomal membrane proteins. J Cell Biol 164:863-875. Epub 2004 Mar 2008

Fransen M, Brees C, Baumgart E, Vanhooren JC, Baes M, Mannaerts GP, van Veldhoven PP (1995) Identification and characterization of the putative human peroxisomal Cterminal targeting signal import receptor. J Biol Chem 270:7731-7736 
Freeman BC, Morimoto RI (1996) The human cytosolic molecular chaperones hsp90, hsp70 (hsc70) and hdj-1 have distinct roles in recognition of a non-native protein and protein refolding. EMBO J 15:2969-2979

Frydman J (2001) Folding of newly translated proteins in vivo: the role of molecular chaperones. Annu Rev Biochem 70:603-647

Frydman J, Nimmesgern E, Oktsuka K, Hartl FU (1994) Folding of nascent polypeptide chains in a high molecular mass assembly with molecular chaperones. Nature 370:111117

Galigniana MD, Harrell JM, Murphy PJ, Chinkers M, Radanyi C, Renoir JM, Zhang M, Pratt WB (2002) Binding of hsp90-associated immunophilins to cytoplasmic dynein: direct binding and in vivo evidence that the peptidylprolyl isomerase domain is a dynein interaction domain. Biochemistry 41:13602-13610

Gatto GJ Jr, Geisbrecht BV, Gould SJ, Berg JM (2000) Peroxisomal targeting signal-1 recognition by the TPR domains of human PEX5. Nat Struct Biol 7:1091-1095

Gautschi M, Mun A, Ross S, Rospert S, Wu Y, Hu Z, Thompson LJ, Yin LY, Patterson C (2002) A functional chaperone triad on the yeast ribosome. Proc Natl Acad Sci USA 99:4209-4214

Geuze HJ, Murk JL, Stroobants AK, Griffith JM, Kleijmeer MJ, Koster AJ, Verkleij AJ, Distel B, Tabak HF (2003) Involvement of the endoplasmic reticulum in peroxisome formation. Mol Biol Cell 14:2900-2907. Epub 2003 Apr 2904

Gietl C, Faber KN, van der Klei IJ, Veenhuis M (1994) Mutational analysis of the Nterminal topogenic signal of watermelon glyoxysomal malate dehydrogenase using the heterologous host Hansenula polymorpha. Proc Natl Acad Sci USA 91:3151-3155

Girzalsky W, Rehling P, Stein K, Kipper J, Blank L, Kunau W-H, Erdmann R (1999) Involvement of Pex13p in Pex14p localization and peroxisomal targeting signal 2dependent protein import into peroxisomes. J Cell Biol 144:1151-1162

Glover JR, Andrews DW, Rachubinski RA (1994) Saccharomyces cerevisiae peroxisomal thiolase is imported as a dimer. Proc Natl Acad Sci USA 91:10541-10545

Gould SJ, Collins CS, Wirtz E, Clayton C (2002) Opinion: peroxisomal-protein import: is it really that complex? Nat Rev Mol Cell Biol 3:382-389

Gould SJ, Kalish JE, Morrell JC, Bjorkman J, Urquhart AJ, Crane DI (1996) Pex13p is an $\mathrm{SH} 3$ protein of the peroxisome membrane and a docking factor for the predominantly cytoplasmic PTS1 receptor. J Cell Biol 135:85-95

Gould SJ, Keller GA, Hosken N, Wilkinson J, Subramani S (1989) A conserved tripeptide sorts proteins to peroxisomes. J Cell Biol 108:1657-1664

Gould SJ, Keller GA, Schneider M, Howell SH, Garrard LJ, Goodman JM, Distel B, Tabak $\mathrm{H}$, Subramani S (1990) Peroxisomal protein import is conserved between yeast, plants, insects and mammals. EMBO J 9:85-90

Gouveia AM, Guimaraes CP, Oliveira ME, Reguenga C, Sa-Miranda C, Azevedo JE (2003) Characterization of the peroxisomal cycling receptor, Pex $5 \mathrm{p}$, using a cell-free in vitro import system. J Biol Chem 278:226-232

Gouveia AM, Reguenga C, Oliveira ME, Sa-Miranda C, Azevedo JE (2000) Characterization of peroxisomal Pex $5 p$ from rat liver. Pex $5 p$ in the Pex $5 p-P e x 14 p$ membrane complex is a transmembrane protein. J Biol Chem 275:32444-32451

Harano T, Nose S, Uezu R, Shimizu N, Fujiki Y (2001) Hsp70 regulates the interaction between the peroxisome targeting signal type 1 (PTS1)-receptor Pex5p and PTS1. Biochem J 357:157-165 
Hardonk MJ, Harms G, Koudstaal J (1985) Zonal heterogeneity of rat hepatocytes in the in vivo uptake of $17 \mathrm{~nm}$ colloidal gold granules. Histochemistry 83:473-477

Harper CC, Berg JM, Gould SJ, Harano T, Nose S, Uezu R, Shimizu N, Fujiki Y (2002) PEX5 binds the PTS1 independently of Hsp70 and the peroxin PEX12. J Biol Chem $26: 26$

Harrison CJ, Hayer-Hartl M, Di Liberto M, Hartl F, Kuriyan J (1997) Crystal structure of the nucleotide exchange factor GrpE bound to the ATPase domain of the molecular chaperone DnaK. Science 276:431-435

Hartl FU, Hayer-Hartl M (2002) Molecular chaperones in the cytosol: from nascent chain to folded protein. Science 295:1852-1858

Hausler T, Stierhof YD, Wirtz E, Clayton C (1996) Import of a DHFR hybrid protein into glycosomes in vivo is not inhibited by the folate-analogue aminopterin. J Cell Biol 132:311-324

Hazra PP, Suriapranata I, Snyder WB, Subramani S (2002) Peroxisome remnants in pex3delta cells and the requirement of Pex3p for interactions between the peroxisomal docking and translocation subcomplexes. Traffic 3:560-574

Hettema EH (1998), Import of proteins and fatty acids into peroxisomes. PhD thesis University of Amsterdam

Hettema EH, Girzalsky W, Berg Mvd, Erdmann R, Distel B (2000) Saccharomyces cerevisiae Pex3p and Pex19p are required for proper localization and stability of peroxisomal membrane proteins. EMBO J 19:223-233

Hines V, Brandt A, Griffiths G, Horstmann H, Brutsch H, Schatz G (1990) Protein import into yeast mitochondria is accelerated by the outer membrane protein MAS70. EMBO J 9:3191-3200

Hoepfner D, van den Berg M, Philippsen P, Tabak HF, Hettema EH (2001) A role for Vps1p, actin, and the Myo2p motor in peroxisome abundance and inheritance in Saccharomyces cerevisiae. J Cell Biol 155:979-990. Epub 2001 Dec 2003

Hohfeld J, Minami Y, Hartl FU (1995) Hip, a novel cochaperone involved in the eukaryotic Hsc70/Hsp40 reaction cycle. Cell 83:589-598

Huang S, Ratliff KS, Matouschek A (2002) Protein unfolding by the mitochondrial membrane potential. Nat Struct Biol 9:301-307

Hundley H, Eisenman H, Walter W, Evans T, Hotokezaka Y, Wiedmann M, Craig E (2002) The in vivo function of the ribosome-associated Hsp70, Ssz1, does not require its putative peptide-binding domain. Proc Natl Acad Sci USA 99:4203-4208

Hutchison KA, Dittmar KD, Pratt WB (1994) All of the factors required for assembly of the glucocorticoid receptor into a functional heterocomplex with heat shock protein 90 are preassociated in a self-sufficient protein folding structure, a "foldosome". J Biol Chem 269:27894-27899

Itoh T, Matsuda H, Mori H (1999) Phylogenetic analysis of the third hsp70 homolog in Escherichia coli; a novel member of the Hsc66 subfamily and its possible co-chaperone. DNA Res 6:299-305

James P, Pfund C, Craig EA (1997) Functional specificity among Hsp70 molecular chaperones. Science 275:387-389

Jankowski A, Kim JH, Collins RF, Daneman R, Walton P, Grinstein S (2001) In situ measurements of the $\mathrm{pH}$ of mammalian peroxisomes using the fluorescent protein pHluorin. J Biol Chem 276:48748-48753 
Johnson MA, Snyder WB, Cereghino JL, Veenhuis M, Subramani S, Cregg JM (2001) Pichia pastoris Pex14p, a phosphorylated peroxisomal membrane protein, is part of a PTS-receptor docking complex and interacts with many peroxins. Yeast 18:621-641

Jones JM, Morrell JC, Gould SJ (2001) Multiple distinct targeting signals in integral peroxisomal membrane proteins. J Cell Biol 153:1141-1150

Jones JM, Morrell JC, Gould SJ (2004) PEX19 is a predominantly cytosolic chaperone and import receptor for class 1 peroxisomal membrane proteins. J Cell Biol 164:57-67

Kabani M, Beckerich JM, Brodsky JL (2002a) Nucleotide exchange factor for the yeast Hsp70 molecular chaperone Ssa1p. Mol Cell Biol 22:4677-4689

Kabani M, Beckerich JM, Gaillardin C (2000) Sls1p stimulates Sec63p-mediated activation of Kar2p in a conformation-dependent manner in the yeast endoplasmic reticulum. Mol Cell Biol 20:6923-6934

Kabani M, McLellan C, Raynes DA, Guerriero V, Brodsky JL (2002b) HspBP1, a homologue of the yeast Fes1 and Sls1 proteins, is an Hsc70 nucleotide exchange factor. FEBS Lett 531:339-342

Kawula TH, Lelivelt MJ (1994) Mutations in a gene encoding a new Hsp70 suppress rapid DNA inversion and bgl activation, but not proU derepression, in hns-1 mutant Escherichia coli. J Bacteriol 176:610-619

Kazlauskas A, Poellinger L, Pongratz I (2002) Two distinct regions of the immunophilinlike protein XAP2 regulate dioxin receptor function and interaction with hsp90. J Biol Chem 277:11795-11801

Kikuchi M, Hatano N, Yokota S, Shimozawa N, Imanaka T, Taniguchi H (2004) Proteomic analysis of rat liver peroxisome: presence of peroxisome-specific isozyme of Lon protease. J Biol Chem 279:421-428. Epub 2003 Oct 2015

Kim S, Schilke B, Craig EA, Horwich AL (1998) Folding in vivo of a newly translated yeast cytosolic enzyme is mediated by the SSA class of cytosolic yeast Hsp70 proteins. Proc Natl Acad Sci USA 95:12860-12865

Klein AT, Barnett P, Bottger G, Konings D, Tabak HF, Distel B (2001) Recognition of peroxisomal targeting signal type 1 by the import receptor Pex 5 p. J Biol Chem 276:15034-15041

Klein AT, van den Berg M, Bottger G, Tabak HF, Distel B (2002) Saccharomyces cerevisiae acyl-CoA oxidase follows a novel, non-PTS1, import pathway into peroxisomes that is dependent on Pex5p. J Biol Chem 277:25011-25019

Koch A, Thiemann M, Grabenbauer M, Yoon Y, McNiven MA, Schrader M (2003) Dynamin-like protein 1 is involved in peroxisomal fission. J Biol Chem 278:8597-8605. Epub 2002 Dec 8523

Komori M, Kiel JA, Veenhuis M (1999) The peroxisomal membrane protein Pex14p of Hansenula polymorpha is phosphorylated in vivo. FEBS lett 457:397-399

Lametschwandtner G, Brocard C, Fransen M, van Veldhoven P, Berger J, Hartig A (1998) The difference in recognition of terminal tripeptides as peroxisomal targeting signal 1 between yeast and human is due to different affinities of their receptor Pex $5 \mathrm{p}$ to the cognate signal and to residues adjacent toiIt. J Biol Chem 273:33635-33643

Lazarow PB, Fujiki Y (1985) Biogenesis of peroxisomes. Annu Rev Cell Biol 1:489-530

Legakis J, Terlecky S (2001) PTS2 protein import into mammalian peroxisomes. Traffic 2:252-260

Leiper JM, Oatey PB, Danpure CJ (1996) Inhibition of alanine:glyoxylate aminotransferase 1 dimerization is a prerequisite for its peroxisome-to-mitochondrion mistargeting in Primary Hyperoxaluria Type 1. J Cell Biol 135:939-951 
Li X, Gould SJ (2003) The dynamin-like GTPase DLP1 is essential for peroxisome division and is recruited to peroxisomes in part by PEX11. J Biol Chem 278:17012-17020 Epub 12003 Mar 17014

Liberek K, Marszalek J, Ang D, Georgopoulos C, Zylicz M (1991) Escherichia coli DnaJ and GrpE heat shock proteins jointly stimulate ATPase activity of DnaK. Proc Natl Acad Sci USA 88:2874-2878

Louvion JF, Abbas-Terki T, Picard D (1998) Hsp90 is required for pheromone signaling in yeast. Mol Biol Cell 9:3071-3083

Marzioch M, Erdmann R, Veenhuis M, Kunau W-H (1994) PAS7 encodes a novel yeast member of the WD-40 protein family essential for import of 3-oxoacyl-CoA thiolase, a PTS2-containing protein, into peroxisomes. EMBO J 13:4908-4918

Matouschek A, Pfanner N, Voos W, Strobel G, Zollner A, Angermayr M, Bandlow W (2000) Protein unfolding by mitochondria. The Hsp70 import motor. EMBO Rep 1:404-410

Matsumura T, Otera H, Fujiki Y (2000) Disruption of the interaction of the longer isoform of Pex $5 \mathrm{p}$, Pex $5 \mathrm{pL}$, with Pex $7 \mathrm{p}$ abolishes peroxisome targeting signal type 2 protein import in mammals. Study with a novel Pex5-impared Chinese hamster ovary cell mutant. J Biol Chem 275:21715-21721

Mayer MP, Schroder H, Rudiger S, Paal K, Laufen T, Bukau B (2000) Multistep mechanism of substrate binding determines chaperone activity of Hsp70. Nat Struct Biol 7:586-593

McNew JA, Goodman JM (1996) The targeting and assembly of peroxisomal proteins: some old rules do not apply. Trends Biochem Sci 21:54-58

Misselwitz B, Staeck O, Rapoport TA (1998) J proteins catalytically activate Hsp70 molecules to trap a wide range of peptide sequences. Mol Cell 2:593-603

Motley A, Lumb MJ, Patel PB, Jennings PR, Zoysa PD, Wanders RJA, Tabak HF, Danpure CJ (1995) Identification of the peroxisomal targeting sequence of mammalian alanine: glyoxylate aminotransferase 1 . Increased degeneracy and contaxt specificity of the mammalian PTS1 motif and implications for the peroxisome-to-mitochondrion mistargeting of AGT in primary hyperoxaluria type 1. J Cell Biol 131:95-109

Motley AM, Hettema EH, Ketting R, Plasterk R, Tabak HF (2000) Caenorhabditis elegans has a single pathway to target matrix proteins to peroxisomes. EMBO reports 1:40-46

Nelson R, T Z, C N, M W-W, EA C (1992) The translation machinery and 70 kd heat shock protein cooperate in protein synthesis. Cell 71:97-105

Neuberger G, Maurer-Stroh S, Eisenhaber B, Hartig A, Eisenhaber F (2003) Motif refinement of the peroxisomal targeting signal 1 and evaluation of taxon-specific differences. J Mol Biol 328:567-579

Ngosuwan J, Wang NM, Fung KL, Chirico WJ (2002) Roles of cytosolic Hsp70 and Hsp40 molecular chaperones in post-translational translocation of presecretory proteins into the endoplasmic reticulum. J Biol Chem 19:19

Nicola A, W C, A H (1999) Co-translational folding of an alphavirus capsid protein in the cytosol of living cells. Nat Cell Biol 1:341-345

Nicolet CM, Craig EA (1989) Isolation and characterization of STI1, a stress-inducible gene from Saccharomyces cerevisiae. Mol Cell Biol 9:3638-3646

Novikoff PM, Novikoff AB (1972) Peroxisomes in absorptive cells of mammalian small intestine. J Cell Biol 53:532-560 
Pfund C, Lopez-Hoyo N, Ziegelhoffer T, Schilke BA, Lopez-Buesa P, Walter WA, Craig EA (1998) The molecular chaperone Ssb from Saccharomyces cerevisiae is a component of the ribosome-nascent chain complex. EMBO J 17:3981-3989

Picard D, Khursheed B, Garabedian MJ, Fortin MG, Lindquist S, Yamamoto KR (1990) Reduced levels of hsp90 compromise steroid receptor action in vivo. Nature 348:166168

Pishvaee B, Costaguta G, Yeung BG, Ryazantsev S, Greener T, Greene LE, Eisenberg E, McCaffery JM, Payne GS (2000) A yeast DNA J protein required for uncoating of clathrin-coated vesicles in vivo. Nat Cell Biol 2:958-963

Pratt WB, Krishna P, Olsen LJ (2001) Hsp90-binding immunophilins in plants: the protein movers. Trends Plant Sci 6:54-58

Purdue PE, Yang X, Lazarow PB (1998) Pex18p and Pex21p, a novel pair of related peroxins essential for peroxisomal targeting by the PTS2 pathway. J Cell Biol 143:18591869

Raynes DA, Guerriero V Jr (1998) Inhibition of Hsp70 ATPase activity and protein renaturation by a novel Hsp70-binding protein. J Biol Chem 273:32883-32888

Reguenga C, Oliveira ME, Gouveia AM, Sa-Miranda C, Azevedo JE (2001) Characterization of the mammalian peroxisomal import machinery: Pex $2 p, \operatorname{Pex} 5 p, \operatorname{Pex} 12 p$, and Pex14p are subunits of the same protein assembly. J Biol Chem 276:29935-29942

Rehling P, Marzioch M, Niessen F, Wittke E, Veenhuis M, Kunau W-H (1996) The import receptor for the peroxisomal targeting signal 2 (PTS2) in Saccharomyces cerevisiae is encoded by the PAS7 gene. EMBO J 15:2901-2913

Rottensteiner H, Kramer A, Lorenzen S, Stein K, Landgraf C, Volkmer-Engert R, Erdmann R (2004) Peroxisomal membrane proteins contain common Pex19p-binding sites that are an integral part of their targeting signals. Mol Biol Cell 15:3406-3417. Epub 2004 May 3407

Rudiger S, Germeroth L, Schneider-Mergener J, Bukau B (1997) Substrate specificity of the DnaK chaperone determined by screening cellulose-bound peptide libraries. EMBO J 16:1501-1507

Ruigrok CCM, de Jonge W, Tabak HF, Braakman LJ (manuscript in preparation) Efficiency of peroxisomal protein import is determined by competition between translocation and a change into import-incompetence

Sacksteder KA, Jones JM, South ST, Li X, Liu Y, Gould SJ (2000) PEX19 binds multiple peroxisomal membrane proteins, is predominantly cytoplasmic, and is required for peroxisome membrane synthesis. J Cell Biol 148:931-944

Scheufler C, Brinker A, Bourenkov G, Pegoraro S, Moroder L, Bartunik H, Hartl FU, Moarefi I (2000) Structure of TPR domain-peptide complexes: critical elements in the assembly of the Hsp70-Hsp90 multichaperone machine. Cell 101:199-210

Schmid D, Baici A, Gehring H, Christen P, Reinstein J, Bukau B (1994) Kinetics of molecular chaperone action. Science 263:971-973

Schulte TW, Blagosklonny MV, Ingui C, Neckers L (1995) Disruption of the Raf-1-Hsp90 molecular complex results in destabilization of Raf-1 and loss of Raf-1-Ras association. J Biol Chem 270:24585-24588

Sichting M, Schell-Steven A, Prokisch H, Erdmann R, Rottensteiner H (2003) Pex7p and Pex20p of Neurospora crassa function together in PTS2-dependent protein import into peroxisomes. Mol Biol Cell 14:810-821

Silver PA, Way JC, James P, Pfund C, Craig EA (1993) Eukaryotic DnaJ homologs and the specificity of Hsp70 activity. Cell 74:5-6 
Silverstein AM, Galigniana MD, Kanelakis KC, Radanyi C, Renoir JM, Pratt WB (1999) Different regions of the immunophilin FKBP52 determine its association with the glucocorticoid receptor, hsp90, and cytoplasmic dynein. J Biol Chem 274:36980-36986

Sondermann H, Ho AK, Listenberger LL, Siegers K, Moarefi I, Wente SR, Hartl FU, Young JC (2002) Prediction of novel Bag-1 homologs based on structure/function analysis identifies Snllp as an Hsp70 co-chaperone in Saccharomyces cerevisiae. J Biol Chem 277:33220-33227

Soto U, Pepperkok R, Ansorge W, Just WW (1993) Import of firefly luciferase into mammalian peroxisomes in vivo requires nucleoside triphosphates. Exp Cell Res 205:66-75

South ST, Baumgart E, Gould SJ (2001) Inactivation of the endoplasmic reticulum protein translocation factor, Sec61p, or its homolog, Ssh1p, does not affect peroxisome biogenesis. Proc Natl Acad Sci USA 98:12027-12031. Epub 12001 Oct 12022

South ST, Sacksteder KA, Li X, Liu Y, Gould SJ (2000) Inhibitors of COPI and COPII do not block PEX3-mediated peroxisome synthesis. J Cell Biol 149:1345-1359

Strobel G, Zollner A, Angermayr M, Bandlow W (2002) Competition of spontaneous protein folding and mitochondrial import causes dual subcellular location of major adenylate kinase. Mol Biol Cell 13:1439-1448

Subramani S (1996) Protein translocation into peroxisomes. J Biol Chem 271:32483-32486

Swinkels BW, Gould SJ, Bodnar AG, Rachubinski RA, Subramani S (1991) A novel, cleavable peroxisomal targeting signal at the amino-terminus of the rat 3-ketoacylCoA thiolase. EMBO J 10:3255-3262

Szilard RK, Titorenko VI, Veenhuis M, Rachubinski RA (1995) Pay 32p of the yeast Yarrowia lipolytica is an intraperoxisomal component of the matrix protein translocation machinery. J Cell Biol 131:1453-1469

Tabak HF, Murk JL, Braakman I, Geuze HJ (2003) Peroxisomes start their life in the endoplasmic reticulum. Traffic 4:512-518

Takayama S, Bimston DN, Matsuzawa S, Freeman BC, Aime-Sempe C, Xie Z, Morimoto RI, Reed JC (1997) BAG-1 modulates the chaperone activity of Hsp70/Hsc70. EMBO J 16:4887-4896

Terlecky SR, Dice JF (1993) Polypeptide import and degradation by isolated lysosomes. J Biol Chem 268:23490-23495

Terlecky SR, Nuttley WM, McCollum D, Sock E, Subramani S (1995) The Pichia pastoris peroxisomal protein PAS8p is the receptor for the C-terminal tripeptide peroxisomal targeting signal. EMBO J 14:3627-3634

Titorenko VI, Nicaud JM, Wang H, Chan H, Rachubinski RA (2002) Acyl-CoA oxidase is imported as a heteropentameric, cofactor-containing complex into peroxisomes of Yarrowia lipolytica. J Cell Biol 156:481-494

Titorenko VI, Smith JJ, Szilard RK, Rachubinski RA (1998) Pex20p of the yeast Yarrowia lipolytica is required for the oligomerization of thiolase in the cytosol and for its targeting to the peroxisome. J Cell Biol 142:403-420

Tsukamoto T, Hata S, Yokota S, Miura S, Fujiki Y, Hijikata M, Miyazawa S, Hashimoto T, Osumi T (1994) Characterization of the signal peptide at the amino terminus of the rat peroxisomal 3-ketoacyl-CoA thiolase precursor. J Biol Chem 269:6001-6010

Ungewickell E, Ungewickell H, Holstein SE, Lindner R, Prasad K, Barouch W, Martin B, Greene LE, Eisenberg E (1995) Role of auxillin in uncoating clathrin-coated vesicles. Nature 378:632-635 
Urquhart AJ, Kennedy D, Gould SJ, Crane DI (2000) Interaction of Pex5p, the type 1 peroxisome targeting signal receptor, with the peroxisomal membrane proteins Pex $14 \mathrm{p}$ and Pex13p. J Biol Chem 275:4127-4136

van der Klei IJ, Hilbrands RE, Swaving GJ, Waterham HR, Vrieling EG, Titorenko VI, Cregg JM, Harder W, Veenhuis M (1995) The Hansenula polymorpha PER3 gene is essential for the import of PTS1 proteins into the peroxisomal matrix. J Biol Chem 270:17229-17236

Van der Leij I, Franse MM, Elgersma Y, Distel B, Tabak HF (1993) PAS10 is a tetratricopeptide-repeat protein that is essential for the import of most matrix proteins into peroxisomes of Saccharomyces cerevisiae. Proc Natl Acad Sci USA 90:11782-11786

van der Lende TR, Breeuwer P, Abee T, Konings WN, Driessen AJ (2002) Assessment of the microbody luminal $\mathrm{pH}$ in the filamentous fungus Penicillium chrysogenum. Biochim Biophys Acta 1589:104-111

Van Roermund CW, De Jong M, L IJ, Van Marle J, Dansen TB, Wanders RJ, Waterham HR (2004) The peroxisomal lumen in Saccharomyces cerevisiae is alkaline. J Cell Sci 117:4231-4237

Verner K, Schatz G (1987) Import of an incompletely folded precursor protein into isolated mitochondria requires an energized inner membrane, but no added ATP. EMBO J 6:2449-2456

Voorn-Brouwer T, Kragt A, Tabak HF, Distel B (2001) Peroxisomal membrane proteins are properly targeted to peroxisomes in the absence of COPI- and COPII-mediated vesicular transport. J Cell Sci 114:2199-2204

Walton PA, Wendland M, Subramani S, Rachubinski RA, Welch WJ (1994) Involvement of 70-kD heat-shock proteins in peroxisomal import. J Cell Biol 125:1037-1046

Wendland M, Subramani S (1993) Cytosol-dependent peroxisomal protein import in a permeabilized cell system. J Cell Biol 120:675-685

Werner-Washburne M, Stone DE, Craig EA (1987) Complex interactions among members of an essential subfamily of hsp70 genes in Saccharomyces cerevisiae. Mol Cell Biol $7: 2568-2577$

Wiemer E, Nuttley WM, Bertolaet BL, Li X, Francke U, Wheelock MJ, Anne UK, Johnson KR, Subramani S (1995a) The human PTS1 receptor restores peroxisomal protein import deficiency in cells from patients with fatal peroxisomal disorders. J Cell Biol 130:51-65

Wiemer EA, Terlecky SR, Nuttley WM, Subramani S, van der Klei IJ, Hilbrands RE, Swaving GJ, Waterham HR, Vrieling EG, Titorenko VI, Cregg JM, Harder W, Veenhuis M (1995b) Characterization of the yeast and human receptors for the carboxyterminal tripeptide peroxisomal targeting signal. Cold Spring Harb Symp Quant Biol 60:637-648. Biotechnology Institute, University of Groningen, Haren, The Netherlands

Wimmer B, Lottspeich F, van der Klei I, Veenhuis M, Gietl C (1997) The glyoxysomal and plastid molecular chaperones (70-kDa heat shock protein) of watermelon cotyledons are encoded by a single gene. Proc Natl Acad Sci USA 94:13624-13629

$\mathrm{Xu}$ Y, Lindquist S (1993) Heat-shock protein hsp90 governs the activity of pp60v-src kinase. Proc Natl Acad Sci USA 90:7074-7078

Yang X, Purdue P, Lazarow P (2001) Ecilp uses a PTS1 to enter peroxisomes: either its own or that of a partner, Dcilp. Eur J Cell Biol 80:126-138

Young JC, Hoogenraad NJ, Hartl FU, Obermann WM (2003) Molecular chaperones hsp90 and hsp70 deliver preproteins to the mitochondrial import receptor tom70. Cell $112: 41-50$ 
Young JC, Obermann WM, Hartl FU (1998) Specific binding of tetratricopeptide repeat proteins to the C-terminal 12-kDa domain of hsp90. J Biol Chem 273:18007-18010

Zhang JW, Lazarow PB (1994) PEB1 (PAS7) in Saccharomyces cerevisiae encodes a hydrophilic, intraperoxisomal protein which is a member of the WD repeat family and is essential for the import of thiolase into peroxisomes. J Cell Biol 129:65-80

Braakman, Ineke

Department of Cellular Protein Chemistry, Utrecht University, Padualaan 8, $3584 \mathrm{CH}$, Utrecht, The Netherlands

i.braakman@chem.uu.nl

de Jonge, Wim

Department of Cellular Protein Chemistry, Utrecht University, Padualaan 8, $3584 \mathrm{CH}$, Utrecht, The Netherlands. Current adress: Institute of Information and Computing Sciences, Utrecht University, Padualaan 14, 3584CH Utrecht, The Netherlands.

Tabak, Henk F.

Department of Cellular Protein Chemistry, Utrecht University, Padualaan 8, $3584 \mathrm{CH}$, Utrecht, The Netherlands, and Laboratory of Cell Biology, University Medical Center Utrecht and Center for Biomedical Genetics, 3584 CX Utrecht, The Netherlands 